\title{
Metabolomics as a Promising Resource Identifying Potential Biomarkers for Inflammatory Bowel Disease
}

\author{
Cristina Bauset ${ }^{1}$, Laura Gisbert-Ferrándiz ${ }^{1}\left(\mathbb{D}\right.$ and Jesús Cosín-Roger ${ }^{2, *}$ \\ 1 Department of Pharmacology and CIBER, Faculty of Medicine, University of Valencia, 46010 Valencia, Spain; \\ baupas@alumni.uv.es (C.B.); laura.gisbert@uv.es (L.G.-F.) \\ 2 Hospital Dr. Peset, Fundación para la Investigación Sanitaria y Biomédica de la Comunitat Valenciana, \\ FISABIO, 46017 Valencia, Spain \\ * Correspondence: jesus.cosin@uv.es; Tel.: +34-963851234
}

Citation: Bauset, C.;

Gisbert-Ferrándiz, L.; Cosín-Roger, J.

Metabolomics as a Promising

Resource Identifying Potential

Biomarkers for Inflammatory Bowel

Disease. J. Clin. Med. 2021, 10, 622.

https://doi.org/10.3390/jcm10040622

Academic Editor: Gian Paolo Caviglia

Received: 22 December 2020

Accepted: 2 February 2021

Published: 6 February 2021

Publisher's Note: MDPI stays neutral with regard to jurisdictional claims in published maps and institutional affiliations.

Copyright: (c) 2021 by the authors. Licensee MDPI, Basel, Switzerland. This article is an open access article distributed under the terms and conditions of the Creative Commons Attribution (CC BY) license (https:// creativecommons.org/licenses/by/ $4.0 /)$.

\begin{abstract}
Inflammatory bowel disease (IBD) is a relapsing chronic disorder of the gastrointestinal tract characterized by disruption of epithelial barrier function and excessive immune response to gut microbiota. The lack of biomarkers providing early diagnosis or defining the status of the pathology difficulties an accurate assessment of the disease. Given the different metabolomic profiles observed in IBD patients, metabolomics may reveal prime candidates to be studied, which may help in understanding the pathology and identifying novel therapeutic targets. In this review, we summarize the most current advances describing the promising metabolites such as lipids or amino acids found through untargeted metabolomics from serum, faecal, urine and biopsy samples.
\end{abstract}

Keywords: inflammatory bowel disease; metabolomics; biomarkers

\section{Introduction}

Inflammatory bowel disease (IBD) is a chronic inflammatory alteration of the gastrointestinal tract which comprises ulcerative colitis (UC) and Crohn's disease (CD). Although both pathologies are characterized by the presence of relapsing and remitting episodes associated with intestinal inflammation and epithelial injury, these diseases present notable differences. On the one hand, UC manifests as a diffuse inflammation affecting the mucosal layer and is mainly located at the rectum and colon. The most frequent symptoms of UC patients are rectal bleeding, weight loss, bloody diarrhoea, fever and, to a lesser extent, abdominal pain. On the other hand, $C D$ is characterized by a localized and well-defined transmural inflammation affecting several layers, which can appear in any part of the gastrointestinal tract, although it affects more frequently the terminal ileum and colon. In this case, symptoms of $\mathrm{CD}$ patients present several differences depending on the disease location, behaviour and extent, the most frequent ones being abdominal pain, weight loss, diarrhoea, fatigue and fever [1].

The incidence and prevalence of IBD is continuously increasing each year, and it has become a crucial disease in both Western and newly industrialized countries that needs to be treated as an important public health pathology [2]. Despite all the great progress that has been achieved during the last two decades, the aetiology of IBD is still not well known. To date, it is assumed that IBD is a multifactorial disease in which different factors such as genetic, environmental, microbial and immunological are responsible for the onset of this disease [3]. Therefore, it is still challenging to better elucidate and define the aetiopathogenic mechanisms involved in IBD in order to stablish new pharmacological targets with the aim to obtain a pharmacological treatment that induces a complete remission of the pathology.

Once an IBD patient is diagnosed, the specific subclassification of IBD is sometimes complicated, since it is still difficult to differentiate between $C D$, UC and other gastrointestinal diseases. In addition, the clinical symptoms of IBD patients do not often correlate 
with the disease activity, which makes even more difficult to stablish a precise diagnosis and a pharmacological treatment for each patient [4]. Therefore, clinicians need more tools in order to stablish a "gold standard" test to diagnose, assess the disease severity or even evaluate the response to the pharmacological treatment. With this goal in mind, during recent decades, the search of IBD biomarkers has been extensive, and several of them have been introduced into the clinical practice. Among these biomarkers, we can find some serological antibodies such as perinuclear anti-neutrophil cytoplasmic antibodies (pANCA), anti-saccharomyces cerevisiae antibodies (ASCA), antibodies against exocrine pancreas (PABs), circulating non-coding RNAs including mi-RNAs and lncRNA, C-reactive protein (CRP), cathelicidin, Trefoil factor 3 (TFF3) [5]. Nevertheless, the use of most of the reported biomarkers is still controversial, and unfortunately, there is still a lack of a set of biomarkers that allows clinicians to better diagnose or evaluate the clinical disease activity in IBD patients.

Among all the omics that have been recently developed, metabolomics is one of the most recent technique that has bounced into IBD. This is due to the fact that metabolomics has the potential not only to identify specific biomarkers for diagnosis and monitoring the disease behaviour, but also to elucidate specific molecular mechanisms involved in this pathology. In fact, this omic is being used in the study of several diseases such as cancer, diabetes, multiple sclerosis, cardiovascular ischemia. Metabolomics is the largescale study of small molecules, known as metabolites, in biological samples, which, in case of IBD patients, can be biopsies, stool, plasma and urine. Although most of the studies performed so far have used the proton nuclear magnetic resonance ( $\left.{ }^{1} \mathrm{H}-\mathrm{NMR}\right)$, advances in methodology and mass spectroscopy (MS) have also introduced this technique in the analysis of the metabolomic profiles in biological samples [6].

Despite all the metabolomic studies performed in IBD patients so far, the specific metabolic alterations in these patients still remain unclear. Nevertheless, it is clear that the identification of specific metabolic signatures might be extremely useful in the diagnosis of both UC and CD and also in the evaluation of the disease activity. Therefore, in the present review, we describe all the different metabolites that have been differentially detected in both UC and CD patients, and we try to clarify whether these compounds might represent promising biomarkers for IBD patients or even the components of metabolomic pathways, which can be considered as pharmacological targets for IBD treatment.

\section{Tricarboxylic Acid Cycle (TCA) Intermediates}

The tricarboxylic acid cycle (TCA) cycle, also named as the Krebs cycle, constitutes a key protagonist in cell metabolism. It includes a loop of consecutive reactions that obtain reducing equivalents $\mathrm{NADH}$ and FADH2, which are essential to transfer electrons to the mitochondrial respiratory chain, also named as the electron transport chain (ETC). This metabolic pathway involves different specific metabolites such as citrate, isocitrate, $\alpha$-ketoglutarate $(\alpha-\mathrm{KG})$, succinyl-CoA, succinate, fumarate, malate and oxaloacetate [7]. In this section, we describe all the metabolic alterations of these TCA cycle intermediates detected in IBD patients. In Table 1, we have summarized all these reported metabolic changes including the alteration observed, the group of patients analysed, the type of sample and technique used in each study. 
Table 1. Differential abundance of tricarboxylic acid cycle (TCA) cycle intermediates in IBD patients. Crohn's disease (CD), ulcerative colitis (UC), colon carcinoma patients (CCR), ultra-high performance liquid chromatography/tandem mass spectroscopy (UPLC-MS/MS), proton nuclear magnetic resonance $\left({ }^{1} \mathrm{H}-\mathrm{NMR}\right)$, gas chromatography/mass spectrometry (GC/MS).

\begin{tabular}{|c|c|c|c|c|c|}
\hline Metabolite & Alteration & Patients & Technique & Sample & Reference \\
\hline \multirow{9}{*}{ Citrate } & Decreased & CD vs. UC and control & UPLC-MS/MS & Serum & [10] \\
\hline & Decreased & CD and UC vs. control & ${ }^{1} \mathrm{H}-\mathrm{NMR}$ & Urine & [11] \\
\hline & Decreased & IBD vs. non-IBD & ${ }^{1} \mathrm{H}-\mathrm{NMR}$ & Serum and Urine & [12] \\
\hline & Increased & Active IBD vs. IBD in remission & ${ }^{1} \mathrm{H}-\mathrm{NMR}$ & Serum and Urine & [12] \\
\hline & Decreased & CD and UC vs. control & ${ }^{1} \mathrm{H}-\mathrm{NMR}$ & Serum and Urine & [8] \\
\hline & Increased & CD vs. UC & ${ }^{1} \mathrm{H}-\mathrm{NMR}$ & Serum & [8] \\
\hline & Decreased & IBD vs. non-IBD & NMR & Urine & [9] \\
\hline & Decreased & $\begin{array}{l}\text { Damaged vs. non-damaged } \\
\text { UC tissue }\end{array}$ & GC/MS & Intestinal Biopsies & [16] \\
\hline & Unchanged & $\begin{array}{c}\text { Paediatric IBD vs. paediatric } \\
\text { non-IBD }\end{array}$ & ${ }^{1} \mathrm{H}-\mathrm{NMR}$ & Faecal & [14] \\
\hline \multirow{2}{*}{ Aconitate } & Decreased & CD vs. UC and control & UPLC-MS/MS & Serum & [10] \\
\hline & Decreased & IBD vs. non-IBD & NMR & Urine & [9] \\
\hline$\alpha$-ketoglutarate & Decreased & CD vs. UC and control & UPLC-MS/MS & Serum & [10] \\
\hline \multirow{9}{*}{ Succinate } & Decreased & CD vs. UC and control & UPLC-MS/MS & Serum & [10] \\
\hline & Decreased & $\begin{array}{c}\text { IBD vs. non-IBD } \\
\text { Active IBD vs. IBD in remission }\end{array}$ & ${ }^{1} \mathrm{H}-\mathrm{NMR}$ & Urine & [12] \\
\hline & Decreased & CD and UC vs. control & ${ }^{1} \mathrm{H}-\mathrm{NMR}$ & Urine & {$[8]$} \\
\hline & Decreased & IBD vs. non-IBD & NMR & Urine & [9] \\
\hline & Decreased & CD and UC vs. non-IBD & ${ }^{1} \mathrm{H}-\mathrm{NMR}$ & Intestinal Biopsies & [15] \\
\hline & Decreased & $\begin{array}{l}\text { Damaged vs. non-damaged } \\
\text { UC tissue }\end{array}$ & GC/MS & Intestinal Biopsies & [16] \\
\hline & Increased & CD vs. healthy CCR patients & ${ }^{1} \mathrm{H}-\mathrm{NMR}$ & $\begin{array}{l}\text { Intestinal } \\
\text { Resections }\end{array}$ & [17] \\
\hline & Unchanged & $\begin{array}{c}\text { Paediatric IBD vs. paediatric } \\
\text { non-IBD }\end{array}$ & ${ }^{1} \mathrm{H}-\mathrm{NMR}$ & Faecal & [14] \\
\hline & Unchanged & UC and CD vs. control & ${ }^{1} \mathrm{H}-\mathrm{NMR}$ & Faecal & [13] \\
\hline \multirow[b]{2}{*}{ Fumarate } & Decreased & CD vs. UC and control & UPLC-MS/MS & Serum & [10] \\
\hline & Decreased & $\begin{array}{l}\text { Damaged vs. non-damaged } \\
\text { UC tissue }\end{array}$ & GC/MS & Intestinal Biopsies & [16] \\
\hline \multirow[b]{2}{*}{ Malate } & Decreased & CD vs. UC and control & UPLC-MS/MS & Serum & [10] \\
\hline & Decreased & $\begin{array}{l}\text { Damaged vs. non-damaged } \\
\text { UC tissue }\end{array}$ & GC/MS & Intestinal Biopsies & [16] \\
\hline Isocitrate & Decreased & $\begin{array}{c}\text { Damaged vs. non-damaged } \\
\text { UC tissue }\end{array}$ & GC/MS & Intestinal Biopsies & [16] \\
\hline
\end{tabular}

Due to the fact that serum and urine samples can be easily obtained, most metabolomic studies were performed using these biological samples. Growing evidence point to an impaired TCA cycle in IBD patients. In fact, Schicho and colleagues analysed the metabolome of serum, plasma and urine samples of $\mathrm{UC}, \mathrm{CD}$ and healthy controls, and they reported lower levels of citrate in both CD and UC patients compared with control in serum and urine samples, while no differential levels in citrate were detected in plasma samples. In addition, these authors also demonstrated that citrate levels in serum can differentiate 
between $C D$ and $U C$, since $C D$ patients showed higher levels of this metabolite [8]. In line with this, Stephens and colleagues analysed the metabolome of urine samples of CD, $\mathrm{UC}$ and healthy controls, and they showed a significant reduction in the levels of the TCA cycle intermediates citrate, succinate and aconitate in IBD patients compared with healthy controls [9]. More recently, Scoville and colleagues analysed the metabolome of the serum of non-IBD, CD and UC patients and also reported a significant decrease in all the TCA cycle intermediates analysed in CD patients compared with non-IBD or UC patients. Specifically, they showed reduced levels of citrate, aconitate, $\alpha$-ketoglutarate, succinate, fumarate and malate [10].

This differential abundance of TCA cycle intermediates would allow us to (a) discriminate between non-IBD and IBD patients, (b) discriminate between IBD patients and other inflammatory diseases and (c) evaluate the disease activity. Indeed, Alonso and colleagues analysed the metabolome of the urine of several patients with immune-mediated inflammatory diseases (IMIDs), including IBD, and controls. In that study, authors reported reduced levels of citrate in both CD and UC patients compared with healthy controls. In the same study, authors go even further and point to citrate as a possible biomarker of the disease activity specifically in CD patients, since the concentration of this metabolite was significantly lower in those CD patients with a higher degree of disease activity [11]. In this line, Dawiskiba and colleagues collected both serum and urine samples of both active and in remission IBD patients and control subjects and analysed the metabolomic profiles in those samples. In serum samples, they reported a significant decrease in levels of citrate in IBD patients compared with control and increased levels of this metabolite in active IBD patients compared with IBD patients in remission. In addition, they reproduced these observations with the urine samples, and they also detected reduced levels of succinate in IBD patients versus control subjects. However, in this case, they reported lower urine levels of succinate in active IBD patients compared with IBD patients in remission [12]. These studies point to these metabolites as possible biomarkers for monitoring the clinical behaviour of the pathology in IBD patients.

Besides serum and urine samples, faecal samples have also been used in order to analyse the metabolome in IBD patients. In this case, unlike serum and urine samples, there are no significant differences in TCA cycle intermediates measured in faecal samples. In fact, although Marchesi and colleagues showed notable differences of a typical ${ }^{1} \mathrm{H}-\mathrm{NMR}$ spectra of faecal extracts obtained from healthy volunteers and patients with CD and UC, the authors revealed no significant differences between the groups analysed regarding levels of succinate [13]. In line with this, Martin and colleagues also reported no changes in the levels of succinate nor citrate in faecal samples of paediatric CD and UC compared with healthy controls [14]. These differences observed between the metabolomic profiles in faecal samples and those observed in the serum and urine samples are probably due to the involvement of the microbiota, one of the central protagonists in IBD pathology.

Unfortunately, there are few studies that have analysed the metabolomic profiles specifically in intestinal tissues of these patients. Balasubramanian and colleagues obtained intestinal biopsies from both UC and CD patients, and they revealed a significant decrease in levels of succinate in both UC and CD patients compared with healthy controls. However, although they divided the IBD patients in active and remission, they did not observe significant differences between them [15]. Of interest, Ooi and colleagues compared the metabolome of the damaged and normal tissue of intestinal biopsies from UC patients, and they showed that levels of succinate, citrate, fumarate, malate and isocitrate were significantly lower in the damaged area compared with the normal tissue [16].

To our knowledge, there are only two studies that have used intestinal surgical resections from $\mathrm{CD}$ patients in order to analyse metabolomic alterations. In the first study, the authors reported a significant increase in succinate in CD patients compared with control subjects [17]. In addition, in a second study, the same authors expanded their observations, and they have recently reported that succinate levels are even increased in $\mathrm{CD}$ patients with a penetrating behaviour (B3-CD patients) compared with CD patients 
with a stricturing behaviour (B2-CD patients) [18]. This difference in one TCA cycle intermediate reveals the importance of studying the metabolomic patterns specifically in intestinal resections of IBD patients.

Due to the emerging development of several omics, the most recent studies try to integrate the results obtained by different omics in order to have a more complex observation of IBD patients. In this sense, epigenetics can also modify the cell metabolism, which in turn, modulates the metabolite levels in the tissue. In fact, the histone succinylation, lactylation and crotonylation rely on substrates succinyl-coA, lactate and crotonyl-coA levels, respectively. In addition, another TCA component, such as $\alpha$-ketoglutarate, can serve as substrate, donor, cofactor or competitive inhibitor for various epigenetic enzymes [19]. On the other hand, given the great importance of the intestinal microbiota in IBD patients, most of these current studies try to correlate the metabolomics changes with all the alterations observed in intestinal microbiota. Of interest, it has been recently reported that succinate levels are increased in stool samples of paediatric CD patients infected with Clostridioides difficile compared with paediatric CD patients without infection. In this elegant study, the authors associate for the first time a metabolomic alteration with a specific bacterium [20]. In line with this, it has also been recently reported that succinate levels of intestinal aspirates from paediatric IBD patients positively correlates with the invasion of Escherichia Coli [21]. Nevertheless, there is still a gap between all the findings related to the intestinal microbiota and all the different metabolomics profiles reported so far. Therefore, further studies are also needed in order to integrate all the big data generated by these omic approaches, including the microbiota information, and to elucidate the specific molecular mechanisms involved in this pathology.

\section{Lipids}

The term lipid includes a large amount of molecules with a wide variety of different structures and biological functions affecting cell membranes, metabolic processes and signalling pathways, and acting as energy storage sources [22]. Lipids are classified in eight different categories: fatty acids, sterol lipids, sphingolipids, sphingolipids, glycerolipids, glycerophospholipids, prenol lipids, saccharolipids and polyketides [22]. In the following section, we discuss the alterations in lipid profiles detected in IBD patients following the above classification.

\subsection{Fatty Acids}

Firstly, fatty acids constitute a group of compounds that play important roles in the regulation of physiologic and metabolic pathways. Their specific role in inflammation seems to be dual, since some of them exhibit proinflammatory functions, while others possess anti-inflammatory properties. Alterations in their physiological levels are traduced in modifications in lipid cascades and important metabolic signalling pathways that modulate the inflammatory response [23]. All the reported metabolic alterations described in IBD patients regarding fatty acids are summarized in Table 2.

Long-chain (LCFAs), medium-chain (MCFAs) and polyunsaturated fatty acids (PUFAs) have been found altered in serum, plasma, urine, faecal and colonic mucosa samples of IBD subjects compared to non-IBD controls. Lai and colleagues reported decreased levels of LCFAs such as docosahexaenoic acid, linolenic acid and arachidonic acid and MCFAs such as pelargonic acid and caprylic acid in serum of CD patients [23]. In line with this, Daniluk and colleagues also found in serum of paediatric IBD patients decreased levels of the LCFAs acids arachidonic acid and docosahexaenoic acid [24]. Moreover, Scoville and colleagues reproduced those observations and authors described reduced levels in serum samples of several metabolites related to LCFAs, branched chain and monohydroxy fatty acids metabolism in the IBD group in comparison to healthy controls. The same group also demonstrated differences in LCFAs-related pathways in CD patients when compared to UC or control subjects [10]. In addition, authors also highlighted a previous study that 
evidenced that lipid profiles of patients receiving effective treatment, such as infliximab, were similar to controls over time [25].

On the other hand, Jansson and colleagues analysed the metabolome using faecal samples. Of interest, in their study, they distinguished between predominantly ileal CD (ICD) and predominantly colonic CD (CCD) patients, and they found increased amounts of fatty acids such as arachidonic acid, linoleic acid, oleic acid, stearic acid, palmitic acid and 6Z-, 9Z- and 12Z-octadecatrienoic acid in ICD vs. CCD and control individuals [26]. This apparent paradox between the increased levels found in faecal samples and decreased levels in serum samples might be due to deficiencies in gut absorption, which commonly occurs as a result of mucosal inflammation. Nevertheless, Weng and colleagues also performed an untargeted metabolomic analysis of faecal samples, and they found that LCFAs such as arachidic acid, oleic acid and tridecanoic acid, as well as MCFAs such as sebacic acid and isocaproic acid, were decreased in UC and CD patients compared with controls [27].

Other fatty acids that have also been detected in serum of IBD patients are acylcarnitines. However, in this case, it is important to mention that the already published information is still controversial. On the one hand, decreased levels of these fatty acids were observed in the serum of CD patients compared with UC and healthy controls [10]. On the other hand, Lai and colleagues found, also in serum samples, increased levels of certain acylcarnitines such as propionylcarnitine, butyrylcarnitine, isovalerylcarnitine and heptanoylcarnitine [23]. Hence, to address this controversy, future studies are required in order to determine the real levels of these fatty acids and their role in IBD pathogenesis.

Up to this point, most of the evidence points to a reduction in LCFAs and MCFAs in IBD patients compared with non-IBD patients $[10,23,24]$. This fact, together with increased levels of acylcarnitine derivatives, suggest an enhanced $\beta$-oxidation of fatty acids in IBD patients, since the rate-limiting step in the $\beta$-oxidation of fatty acids is the availability of acylcarnitines [23]. Indeed, increased $\beta$-oxidation in IBD patients may be due to higher energy demand in order to recruit immune cells to face inflammation, which results in higher LCFAs consumption. As a consequence to this higher energetic demand and the reduced levels of these fatty acids, the immune response might be aggravated $[10,28]$. For instance, NF- $\mathrm{kB}$ activation involves the production of proinflammatory cytokines [29]. This activation is inhibited when MCFAs and LCFAs bind and activate PPAR- $\gamma$ and PPAR- $\alpha$ receptors, triggering an anti-inflammatory effect [30].

The metabolomic analysis performed by Lai and colleagues and Daniluk and colleagues showed reduced levels of arachidonic acid in serum of adult CD and paediatric UC patients, respectively [23,24]. In addition, Jansson and colleagues analysed the arachidonic acid levels in faecal samples of ICD patients, and they found increased levels of this metabolite in ICD patients, which may be due to malabsorption [26]. At this point, it is important to consider that the inflammatory process implies an increased consumption of fatty acids and increased concentrations of arachidonic acid and docosahexaenoic acid, due to a higher expression of phospholipase A2, which hydrolyses phospholipids into arachidonic acid. Indeed, both arachidonic acid and docosahexaenoic acid are also responsible of increasing the biosynthesis of PUFAs, which in turn, regulate the inflammatory response and play an anti-inflammatory role [24]. On the other hand, the key role of arachidonic acid in inflammation has also been demonstrated, since the expression of the intracellular adhesion molecule ICAM-1 is increased by arachidonic acid, favouring the inflammatory response by recruiting leukocytes [26,31]. Furthermore, arachidonic acid, together with linoleic acid, increase the production of prostaglandins, mediators in the immune response. Nevertheless, in the analysis performed by Jansson and colleagues, prostaglandins were increased in the control cohort compared with IBD patients. Authors stated that those reduced levels of prostaglandins in the CD cohort may be due to malabsorption of both arachidonic and linoleic acids [26]. Even though prostaglandin levels are lower in $C D$ patients when comparing patients in remission with active $C D$-patients, higher levels of prostaglandins are found in the last ones, especially the prostaglandin 
PGE2. This prostaglandin is responsible of activating Th17 lymphocytes, which characterize CD pathology, by activation of dendritic cells and further production of IL-23 by them [32]. Nevertheless, there are not yet studies that demonstrate the correlation between increased levels of prostaglandins with an increase in linoleic and arachidonic acids.

Another type of fatty acids commonly disturbed in IBD patients are short-chain fatty acids (SCFAs). These fatty acids are products of the fermentation of complex carbohydrates by anaerobic gut bacteria $[13,33]$. According to the number of carbons in their structure, different types of SCFAs are described being the most abundant the acetate, propionate and butyrate with two, three or four carbon atoms, respectively [34]. Several studies conclude that SCFAs produced by gut microbiota are preferentially used as energy source by colonic epithelial cells to promote cell growth and modulate the immune response in the gastrointestinal tract by enhancing epithelial barrier [35,36], although the mechanism is not well established yet [37]. This energy is also used to absorb sodium in the colon [38]. Previous studies suggest that the impaired metabolism of SCFAs in IBD patients might be due to a defective uptake from faecal effluents caused by a disruption of the sodiumpotassium pump related to alterations in mucosal cell membranes [15]. SCFAs have been found reduced in faecal and urine extracts of IBD patients in many studies $[9,13,33,39]$. In fact, lower levels of the SCFAs butyrate and propionate were found in faecal samples of IBD patients compared with healthy controls $[13,39]$. In the study performed by Marchesi and colleagues, authors could distinguish between UC cohort and CD cohort, since UC patients did not show such decreases compared with CD patients. Thus, CD group of patients seemed to be more affected by inflammation than UC patients [13]. In addition, Stephens and colleagues also found, in this case in urine samples, reduced levels of acetate in IBD patients compared with healthy subjects [9]. Thus, decreased levels of SCFAs can be associated with the disruption of fermentative gut microbiota community due to gut mucosal inflammation in IBD patients [39]. Besides SCFAs, certain MCFAs such as caprylic acid are also produced by gut microbiota, as described in the study performed by Franzosa and colleagues, where they found in faecal samples reduced levels of caprylic acid [33].

Finally, the last type of fatty acids found altered in IBD patients are PUFAs. In this aspect, Scoville and colleagues found in serum samples decreased PUFAs levels in IBD subjects when compared to non-IBD controls. These levels were even lower in CD patients compared with UC patients [10]. In line with this, Franzosa and colleagues found in faecal samples increased levels of eicosatrienoic, an omega-3 fatty acid, and docosapentaenoic, an omega- 6 fatty acid, which are considered as anti-inflammatory compounds [33]. As mentioned above, these increased levels in faeces may indicate a lack of absorption in the gut due to inflammation. It is important to take into account that, as previously stated in this section, PUFAs play many roles related with the intestinal inflammatory response, since they are responsible of synthetizing inflammatory mediators, such as eicosanoids, and they regulate cell membranes of immune cells $[10,40]$. In addition, they possess a bactericidal activity, since they are capable of affecting bacterial cell membranes [41]. Taking everything together, it is clear that levels of fatty acids are commonly altered in IBD contributing to the inflammatory state, which characterizes this pathology. Hence, fatty acids constitute an important group of metabolites, which can be considered promising biomarkers but further studies including larger and wider number of patients are still needed. 
Table 2. Differential abundance of fatty acids in IBD patients. Crohn's disease (CD), ulcerative colitis (UC), predominantly ileal CD (ICD), predominantly colonic CD (CCD), ultra-high performance liquid chromatography/tandem mass spectroscopy (UPLC-MS/MS), proton nuclear magnetic resonance $\left({ }^{1} \mathrm{H}-\mathrm{NMR}\right)$, gas chromatography/mass spectrometry (GC/MS), liquid chromatography/mass spectrometry (LC/MS), ion cyclotron resonance Fourier transform mass spectrometry (ICR-FT/MS).

\begin{tabular}{|c|c|c|c|c|c|c|}
\hline & Metabolite & Alteration & Patients & Technique & Sample & Reference \\
\hline \multirow{17}{*}{$\begin{array}{l}\text { Long-Chain } \\
\text { Fatty Acids } \\
\text { (LCFAs) }\end{array}$} & \multirow{2}{*}{ Unspecified LCFAs } & Decreased & IBD vs. control & $\begin{array}{l}\text { UPLC- } \\
\text { MS/MS }\end{array}$ & Serum & [10] \\
\hline & & Decreased & CD vs. UC & $\begin{array}{l}\text { UPLC- } \\
\text { MS/MS }\end{array}$ & Serum & [10] \\
\hline & \multirow{2}{*}{ Docosahexaenoic Acid } & Decreased & $\begin{array}{l}\text { Active CD and Inactive CD vs. } \\
\text { control }\end{array}$ & LC/MS & Serum & [23] \\
\hline & & Decreased & Paediatric UC vs. control & LC/MS & Serum & [24] \\
\hline & \multirow{2}{*}{ Linolenic Acid } & Decreased & $\begin{array}{l}\text { Active CD and Inactive CD vs. } \\
\text { control }\end{array}$ & $\mathrm{LC} / \mathrm{MS}$ & Serum & [23] \\
\hline & & Increased & ICD vs. CCD and control & ICR-FT/MS & Faeces & [26] \\
\hline & \multirow{3}{*}{ Arachidonic Acid } & Decreased & $\begin{array}{l}\text { Active CD and Inactive CD vs. } \\
\text { control }\end{array}$ & LC/MS & Serum & [23] \\
\hline & & Decreased & Paediatric UC vs. control & LC/MS & Serum & [24] \\
\hline & & Increased & ICD vs. CCD and control & ICR-FT/MS & Faeces & [26] \\
\hline & Arachidic Acid & Decreased & IBD vs. control & GC/MS & Faeces & [27] \\
\hline & \multirow{2}{*}{ Oleic Acid } & Decreased & IBD vs. control & GC/MS & Faeces & [27] \\
\hline & & Increased & ICD vs. CCD and control & ICR-FT/MS & Faeces & [26] \\
\hline & Tridecanoic Acid & Decreased & IBD vs. control & GC/MS & Faeces & [27] \\
\hline & Palmitic Acid & Increased & ICD vs. CCD and control & ICR-FT/MS & Faeces & [26] \\
\hline & Stearic Acid & Increased & ICD vs. CCD and control & ICR-FT/MS & Faeces & [26] \\
\hline & $\begin{array}{c}\text { 6Z-, 9Z-, 12Z } \\
\text { Octadecatrienoic Acid }\end{array}$ & Increased & ICD vs. CCD and control & ICR-FT/MS & Faeces & [26] \\
\hline & $\begin{array}{l}\text { 2-Hydroxymyristic } \\
\text { acid }\end{array}$ & Decreased & IBD vs. control & $\mathrm{LC} / \mathrm{MS}$ & Faeces & [33] \\
\hline \multirow{5}{*}{$\begin{array}{l}\text { Medium-Chain } \\
\text { Fatty Acids }\end{array}$} & Pelargonic Acid & Decreased & $\begin{array}{l}\text { Active CD and Inactive CD vs. } \\
\text { control }\end{array}$ & LC/MS & Serum & [23] \\
\hline & \multirow[t]{2}{*}{ Caprylic Acid } & Decreased & $\begin{array}{l}\text { Active CD and Inactive CD vs. } \\
\text { control }\end{array}$ & LC/MS & Serum & [23] \\
\hline & & Decreased & IBD vs. control & LC/MS & Faeces & [33] \\
\hline & Sebacic Acid & Decreased & IBD vs. control & GC/MS & Faeces & [27] \\
\hline & Isocaproic Acid & Decreased & IBD vs. control & GC/MS & Faeces & [27] \\
\hline \multirow{7}{*}{$\begin{array}{l}\text { Short-Chain } \\
\text { Fatty Acids }\end{array}$} & \multirow{3}{*}{ Butyrate } & Decreased & IBD vs. control & ${ }^{1} \mathrm{H}-\mathrm{NMR}$ & Faeces & [13] \\
\hline & & Decreased & IBD vs. control & LC/MS & Faeces & [33] \\
\hline & & Decreased & Active CD vs. control & ${ }^{1} \mathrm{H}-\mathrm{NMR}$ & Faeces & [39] \\
\hline & \multirow{2}{*}{ Propionate } & Decreased & IBD vs. control & LC/MS & Faeces & [33] \\
\hline & & Decreased & Active CD vs. control & ${ }^{1} \mathrm{H}-\mathrm{NMR}$ & Faeces & [39] \\
\hline & \multirow{2}{*}{ Acetate } & Decreased & IBD vs. control & ${ }^{1} \mathrm{H}-\mathrm{NMR}$ & Urine & [9] \\
\hline & & Decreased & IBD vs. control & ${ }^{1} \mathrm{H}-\mathrm{NMR}$ & Faeces & [13] \\
\hline \multirow{4}{*}{$\begin{array}{l}\text { Polyunsaturated } \\
\text { Fatty Acids }\end{array}$} & \multirow{2}{*}{$\begin{array}{c}\text { Unspecified } \\
\text { Polyunsaturated Fatty } \\
\text { Acids }\end{array}$} & Decreased & $\begin{array}{l}\text { IBD vs. control } \\
\text { CD vs. UC }\end{array}$ & $\begin{array}{l}\text { UPLC- } \\
\text { MS/MS }\end{array}$ & Serum & [10] \\
\hline & & Decreased & $\begin{array}{l}\text { IBD vs. control } \\
\text { CD vs. UC }\end{array}$ & ${ }^{1} \mathrm{H}-\mathrm{NMR}$ & Serum & [42] \\
\hline & Eicosatrienoic & Increased & IBD vs. control & LC/MS & Faeces & [33] \\
\hline & Docosapentaenoic & Increased & IBD vs. control & LC/MS & Faeces & [33] \\
\hline \multicolumn{2}{|c|}{ Branched-Chain Fatty acids } & Decreased & $\begin{array}{l}\text { IBD vs. control } \\
\text { CD vs. UC }\end{array}$ & $\begin{array}{l}\text { UPLC- } \\
\text { MS/MS }\end{array}$ & Serum & [10] \\
\hline
\end{tabular}




\subsection{Sterol Lipids}

Sterol lipids, derived from condensation of isoprene subunits, constitute a huge class of lipids [22]. In this review, among all the types of sterol lipids described, we specifically focus on bile acids and cholesterols due to their impact on IBD. Alterations of those sterol lipids described in IBD patients are synthetized in Table 3.

Regarding the bile acids pathway, the role of these sterol lipids is to facilitate lipids digestion, and afterwards, they are transformed by commensal microbiota to secondary bile acids [33]. In the metabolomic analysis performed by Franzosa and colleagues using faecal samples, secondary bile acids, such as lithocholate and deoxycholate were found in lower levels in CD patients in comparison to healthy controls, while in contrast, primary bile acids, such as cholate and chenodeoxycholate, were increased in CD patients compared with healthy controls. These differential levels observed in IBD patients can be explained, since primary bile acids are accumulated in the gut due to the fact that the presence of microorganisms responsible of undergoing such deconjugations is reduced and/or their function is impaired in the intestine of IBD patients [33]. In line with this, Weng and colleagues also showed in faecal samples of IBD patients lower levels of bile acids, such as lithocholic acid, chonodeoxycholate and taurolithocholic acid, in comparison to controls. Specifically, glycochenodeoxycholate and glycolithocholic acid were decreased in UC patients [27]. At this point, it is important to consider that vitamin D receptor is activated by lithocholic acid, which protects from bile acid toxicity by promoting synthesis of proinflammatory cytokines and dendritic cells differentiation [43,44]. Moreover, bile acids can suppress immune response when they activate the $G$ protein-coupled receptor 5 , because this receptor inhibits cytokines production $[45,46]$. Therefore, when bile acids are decreased, their anti-inflammatory role is not performed, and the immune response is stronger.

Reinforcing those observations, Scoville and colleagues have recently analysed bile acids, and they also found increased levels of these metabolites in serum of CD patients. In fact, primary and secondary bile acids were increased in $C D$ patients when compared to controls. In contrast, sulphated bile acids such as glycolithocholate sulphate or taurocholenate sulphate were reduced in CD patients in comparison to healthy controls. Interestingly, UC patients exhibited reduced levels of primary bile acids glycochenodeoxycholate glucuronide and secondary bile acids [10]. This difference between both diseases might be due to the fact that $\mathrm{CD}$ is characterized by small bowel malabsorption, while in UC, the small bowel is not often affected. Although malabsorption has also been argued, the fact that authors found alterations in both CD and UC patients suggest that malabsorption in the small bowel is not the only cause of such alterations and that bile acid pathways have different implications in IBD [10]. Indeed, some studies suggest that the increased levels of bile acids in serum of $C D$ subjects are due to an increased bile acid production in order to relieve their lack given the malabsorption problems [25].

Of interest, Jansson and colleagues found higher levels of glycocholate in faecal samples of $C D$ subjects in comparison with healthy controls. In addition, they reported higher levels of certain bile acids specifically in ileal-CD patients compared with colonic-CD patients, such as taurocholate, $3 \alpha, 7 \alpha, 12 \alpha$-trihydroxy- $5 \beta$-cholanate and chenodeoxyglycocholate. It is important to consider that the removal of distal ileum by surgery triggers an accumulation of bile acids given the fact that they are mainly absorbed in that part of the intestine [26]. In fact, some studies have reported alterations in bile acids composition in patients with ileal resection [47]. Hence, some of the metabolites altered in IBD, especially in $\mathrm{CD}$, are not caused by the pathogenic process itself, but they result from the associated small bowel resection [10]. 
Table 3. Differential abundance of sterol lipids in IBD patients. Crohn's disease (CD), ulcerative colitis (UC), predominantly ileal CD (ICD), predominantly colonic CD (CCD), ultra-high performance liquid chromatography/tandem mass spectroscopy (UPLC-MS/MS), proton nuclear magnetic resonance $\left({ }^{1} \mathrm{H}-\mathrm{NMR}\right)$, gas chromatography/mass spectrometry (GC/MS), liquid chromatography/mass spectrometry (LC/MS), ion cyclotron resonance Fourier transform mass spectrometry (ICR-FT/MS).

\begin{tabular}{|c|c|c|c|c|c|c|}
\hline & Metabolite & Alteration & Patients & Technique & Sample & Reference \\
\hline \multirow{25}{*}{ Bile Acids } & \multirow{2}{*}{ Unespecified Bile Acids } & Increased & CD vs. control & UPLC-MS/MS & Serum & [10] \\
\hline & & Decreased & UC vs. control & UPLC-MS/MS & Serum & [10] \\
\hline & $\begin{array}{l}\text { Glycochenodeoxycholate } \\
\text { glucuronide }\end{array}$ & Decreased & UC vs. control & UPLC-MS/MS & Serum & [10] \\
\hline & Deoxycholate & Decreased & UC vs. control & UPLC-MS/MS & Serum & [10] \\
\hline & Taurolithocholate 3-sulphate & Decreased & UC vs. control & UPLC-MS/MS & Serum & [10] \\
\hline & Cholate & Increased & CD vs. control & LC/MS & Faeces & [33] \\
\hline & Chenodeoxycholate & Increased & CD vs. control & LC/MS & Faeces & [33] \\
\hline & Glycocholate & Increased & CD vs. control & ICR-FT/MS & Faecal & [26] \\
\hline & Taurocholate & Increased & ICD vs. CCD and control & ICR-FT/MS & Faecal & [26] \\
\hline & $\begin{array}{c}3 \alpha, 7 \alpha, \\
12 \alpha \text {-trihydroxy-5 } 5 \text {-cholanate }\end{array}$ & Increased & ICD vs. CCD and control & ICR-FT/MS & Faecal & [26] \\
\hline & Chenodeoxyglycocholate & Increased & ICD vs. CCD and control & ICR-FT/MS & Faecal & [26] \\
\hline & $\begin{array}{l}\text { Glycochenoeoxycholate } \\
\text { glucuronide }\end{array}$ & Decreased & UC vs. control & UPLC-MS/MS & Serum & [10] \\
\hline & Glycochenoeoxycholate & Decreased & UC vs. control & GC/MS & Faeces & [27] \\
\hline & Clycolithoghato & Increased & CD vs. control & UPLC-MS/MS & Serum & [10] \\
\hline & Giycointilociloiate & Decreased & UC vs. control & GC/MS & Faeces & [27] \\
\hline & Glycoursodeoxycholate & Increased & CD vs. control & UPLC-MS/MS & Serum & [10] \\
\hline & Ursodeoxycholate & Increased & CD vs. control & UPLC-MS/MS & Serum & [10] \\
\hline & Iith o lis & Decreased & IBD vs. control & GC/MS & Faeces & [27] \\
\hline & Lithocholic acid & Decreased & CD vs. control & LC/MS & Faeces & [33] \\
\hline & Chenodeoxycholate & Decreased & IBD vs. control & GC/MS & Faeces & [27] \\
\hline & & Decreased & IBD vs. control & GC/MS & Faeces & [27] \\
\hline & Taurolithocholic acid & Decreased & CD vs. control & UPLC-MS/MS & Serum & [10] \\
\hline & Taurocholenate sulphate & Decreased & CD vs. control & UPLC-MS/MS & Serum & [10] \\
\hline & Deoyzholato & Decreased & UC vs. control & UPLC-MS/MS & Serum & [10] \\
\hline & Deoxyciloiale & Decreased & CD vs. control & LC/MS & Faeces & [33] \\
\hline \multirow{9}{*}{ Cholesterol } & Unspecified Cholesterol & Decreased & CD vs. control & LC/MS & Faeces & [33] \\
\hline & \multirow{3}{*}{ LDL cholesterol } & \multirow{2}{*}{ Decreased } & IBD vs. control & \multirow{2}{*}{${ }^{1} \mathrm{H}-\mathrm{NMR}$} & \multirow{2}{*}{ Serum } & \multirow{2}{*}{ [42] } \\
\hline & & & CD vs. UC & & & \\
\hline & & Decreased & $\begin{array}{l}\text { IBD active vs. IBD remission } \\
\text { and control }\end{array}$ & ${ }^{1} \mathrm{H}-\mathrm{NMR}$ & Serum & [12] \\
\hline & \multirow{2}{*}{ HDL cholesterol } & \multirow{2}{*}{ Decreased } & IBD vs. control & \multirow{2}{*}{${ }^{1} \mathrm{H}-\mathrm{NMR}$} & \multirow{2}{*}{ Serum } & \multirow{2}{*}{ [42] } \\
\hline & & & CD vs. UC & & & \\
\hline & \multirow{3}{*}{ VLDL cholesterol } & \multirow{2}{*}{ Increased } & IBD vs. control & \multirow{2}{*}{${ }^{1} \mathrm{H}-\mathrm{NMR}$} & \multirow{2}{*}{ Serum } & \multirow{2}{*}{ [42] } \\
\hline & & & CD vs. UC & & & \\
\hline & & Decreased & $\begin{array}{l}\text { IBD active vs. IBD remission } \\
\text { and control }\end{array}$ & ${ }^{1} \mathrm{H}-\mathrm{NMR}$ & Serum & [12] \\
\hline
\end{tabular}

On the other hand, cholesterols are another type of sterol lipids that have also been differentially found in IBD patients. Franzosa and colleagues reported lower levels of cholesterol in the CD group in contrast with healthy individuals in faecal samples [33]. A deeper analysis of the specific cholesterol molecules performed by Williams and colleagues 
revealed that low-density lipoprotein (LDL) cholesterol and high-density lipoprotein (HDL) cholesterol were reduced in serum samples of IBD patients in comparison to the controls subjects. Furthermore, in the same study, authors also compared between CD and UC patients, and both LDL and HDL cholesterols were even more decreased in CD patients when compared to the UC group. In contrast to LDL and HDL levels, very low-density lipoprotein (VLDL) cholesterol was increased in IBD patients compared to controls, as well as in CD versus UC patients. Most of the studies performed so far conclude that IBD is characterized by several lipid metabolism alterations, which are strictly related to chronic inflammation [42]. In fact, the pro-inflammatory cytokines, such as TNF- $\alpha$, IL-1 and IFN- $\gamma$, which are abundant in IBD patients, are responsible of inhibiting lipoprotein lipase (LPL) expression $[48,49]$. This LPL protein hydrolyses circulating triglycerides into chylomicrons and VLDL into free fatty acids and glycerol, which are further converted in HDL and LDL [42]. In addition, the lack of HDL also aggravates the inflammatory state, since its main protein, apolipoprotein A-I, binds to T-lymphocytes and prevents monocyte activation, inhibiting TNF- $\alpha$ production [50,51]. This anti-inflammatory effect of HDL is strongly reinforced by accumulative evidence that reveals a disturbance in the composition of lipoproteins in IBD patients [52,53]. Therefore, given the key role of the cholesterol in inflammation, the specific analysis of these sterol lipids might provide important information about specific molecular mechanisms involved in the aetiopathogenesis of IBD.

\subsection{Sphingolipids, Glycerophoshpolipids, Glycerolipids and Prenol Lipids}

Sphingolipids, as lipidic compounds, act as signalling molecules and are part of cell membranes composition [54]. Structurally, they are constituted by a sphingoid base, such as sphingosine, which is linked, through an amide bond, to an LCFA to form a ceramide. Several studies have documented alterations in ceramides and other derivatives such as lactosylceramide, sphingomyelin or sphingosine 1-phosphate in IBD patients. In this section of the review, alterations in the metabolism of sphingolipids, glycerophospholipids, glycerolipids and prenol lipids detected in IBD patients are summarized in Table 4.

In the metabolomic analysis performed by Franzosa and colleagues, sphingolipids, such as ceramide and sphingomyelin, were found increased in the IBD cohort when compared to healthy subjects in faecal samples [33], whereas Scoville and colleagues reported reduced levels of sphingomyelin in serum of IBD patients [10]. It is important to mention that growing evidence indicate that the inflammatory process might be, in part, promoted by the accumulation of sphingolipids due to an alteration of the sphingolipid metabolic pathway in IBD pathogenesis $[55,56]$. Indeed, sphingomyelin and phosphorylcholine are lipidic cell membrane components, which are synthetized from choline [57], an essential nutrient [58], whose deficiency has been associated with some diseases such as non-alcoholic fatty liver [59]. In this line, numerous studies reported lower levels of this metabolite in serum samples of IBD patients $[8,12,42]$. In addition, Williams and colleagues found differences between $C D$ and UC patients showing reduced levels specifically in CD subjects [42]. In line with this, Balasubramanian and colleagues reinforced these observations, since they found reduced levels of choline in colonic mucosa of IBD patients compared to controls. Moreover, authors also reported that active $\mathrm{CD}$ patients showed even reduced levels of choline compared with patients in remission [15]. On the other hand, it has also been reported that choline acts as a scavenge for free radicals, thus, a lack of choline aggravates inflammation in IBD [42,60]. Furthermore, some studies demonstrate that lymphocyte genes are overexpressed in individuals with reduced levels of choline, promoting the inflammatory response [61]. In addition, choline is also present in the structure of platelet activating factor (PAF), an inflammatory mediator [62]. Due to the inflammatory response that characterizes IBD, these patients show an increase in PAF, which in turn, implies an increased demand of choline for its structure [63]. In fact, transmural inflammation, which characterizes CD patients, might imply higher demand of choline in comparison with UC patients [42]. Hence, this increased requirement of choline might be associated to the decreased levels of this metabolite found in CD patients. 
The alterations in sphingolipids have also been reported in paediatric IBD patients [64]. Indeed, Daniluk and colleagues performed a metabolomic analysis using serum of a paediatric cohort suffering IBD, which were recently diagnosed and not treated yet. In that study, authors found decreased levels of glycerophospholipids, such as lysophosphatydilcholine, phosphatydilcoline, phosphatydilethanolamine and lysophosphatidylethanolamine, in paediatric IBD patients and reduced levels of certain sphingolipids, such as sphingomyelin, specifically in CD patients [24]. Of interest, Daniluk and colleagues reported for the first time increased levels of the sphingolipid lactosylceramide in CD patients compared to the UC cohort, becoming a promising biomarker, which might help in the specific diagnosis of CD or UC. In line with this, a recent study performed by Filimoniuk and colleagues also found in serum of non-treated IBD children increased levels of lactosylceramide in CD compared with UC subjects [65]. Authors suggested that the increased levels of lactosylceramide in the $\mathrm{CD}$ cohort may be due to two different possibilities: these patients suffer alterations in the sphingolipid metabolism, or there is an unknown source of this metabolite, which is abnormally increasing its concentration. At this point, it is important to consider that lactosylceramide is a metabolite highly involved in the inflammatory response, and it is found in many inflammatory cell types such as granulocytes, monocytes or platelets. Moreover, it participates in cell-cell interactions, generation of nitric oxide, phagocytosis or as an intracellular mediator [24]. This metabolite, through generating superoxide species, stimulates the expression of ICAM-1 on endothelial cells surface, which favours the adhesion of neutrophils [66,67]. In fact, neutrophils show high levels of lactosylceramide and the proinflammatory cytokine TNF- $\alpha$ favours, in turn, the lactosylceramide production [68]. In addition, lactosylceramide is also responsible of stimulating phospholipase A2 and arachidonic acid release [69], a lipid mediator in inflammatory disease as previously explained. Therefore, it is clear that lactosylceramide might represent a promising biomarker for IBD patients, which needs to be validated in bigger cohorts of IBD patients and better studied in order to characterize its specific role in IBD.

Table 4. Differential abundance of sphingolipids, glycerophospholipids, glycerolipids, prenol lipids and choline in IBD patients. Crohn's disease (CD), ulcerative colitis (UC), ultra-high performance liquid chromatography/tandem mass spectroscopy (UPLCMS/MS), proton nuclear magnetic resonance $\left({ }^{1} \mathrm{H}-\mathrm{NMR}\right)$, liquid chromatography/mass spectrometry (LC/MS).

\begin{tabular}{|c|c|c|c|c|c|c|}
\hline & Metabolite & Alteration & Patients & Technique & Sample & Reference \\
\hline \multirow{7}{*}{ Sphingolipids } & Ceramide & Increased & CD vs. control & $\mathrm{LC} / \mathrm{MS}$ & Faeces & [33] \\
\hline & \multirow[b]{2}{*}{ Lactosylceramide } & \multirow[b]{2}{*}{ Increased } & $\begin{array}{l}\text { Paediatric CD vs. } \\
\text { paediatric UC }\end{array}$ & $\mathrm{LC} / \mathrm{MS}$ & Serum & {$[24]$} \\
\hline & & & $\begin{array}{c}\text { Paediatric CD vs. } \\
\text { paediatric UC } \\
\text { Paediatric IBD vs. control }\end{array}$ & $\begin{array}{l}\text { UPLC- } \\
\text { MS/MS }\end{array}$ & Serum & {$[65]$} \\
\hline & \multirow{3}{*}{ Sphingomyelin } & Increased & CD vs. control & $\mathrm{LC} / \mathrm{MS}$ & Faeces & [33] \\
\hline & & Decreased & Paediatric CD vs. control & $\mathrm{LC} / \mathrm{MS}$ & Serum & {$[24]$} \\
\hline & & Decreased & UC vs. control & $\begin{array}{l}\text { UPLC- } \\
\text { MS/MS }\end{array}$ & Serum & {$[10]$} \\
\hline & $\begin{array}{l}\text { Sphingosine-1- } \\
\text { phosphate }\end{array}$ & Decreased & $\begin{array}{l}\text { Active CD and inactive } \\
\text { CD vs. control }\end{array}$ & $\mathrm{LC} / \mathrm{MS}$ & Serum & [23] \\
\hline \multirow[t]{3}{*}{ Glycerophospholipids } & $\begin{array}{l}\text { Lysophosphatidylcholine } \\
\text { Phosphatidylcholine, } \\
\text { Phosphatidylethanolamine, } \\
\text { Lysophos- } \\
\text { phatidylethanolamine }\end{array}$ & Decreased & Paediatric IBD vs. control & $\mathrm{LC} / \mathrm{MS}$ & Serum & [24] \\
\hline & Lysophosphatidylcholine & Decreased & Paediatric UC vs. control & $\mathrm{LC} / \mathrm{MS}$ & Serum & [24] \\
\hline & Glycerophosphorylcholine & Decreased & $\begin{array}{l}\text { IBD vs. control } \\
\text { Remission IBD vs. control } \\
\text { Active CD vs. } \\
\text { remission CD }\end{array}$ & ${ }^{1} \mathrm{H}-\mathrm{NMR}$ & $\begin{array}{c}\text { Intestinal } \\
\text { Biopsies }\end{array}$ & {$[15]$} \\
\hline
\end{tabular}


Table 4. Cont

\begin{tabular}{|c|c|c|c|c|c|c|}
\hline & Metabolite & Alteration & Patients & Technique & Sample & Reference \\
\hline \multirow{3}{*}{ Glycerolipids } & \multirow{2}{*}{ Glycerol } & Decreased & IBD vs. control & $\begin{array}{l}\text { UPLC- } \\
\text { MS/MS }\end{array}$ & Serum & [10] \\
\hline & & Increased & CD vs. UC and control & ${ }^{1} \mathrm{H}-\mathrm{NMR}$ & Faeces & [13] \\
\hline & Triacylglycerols & Decreased & IBD vs. control & $\mathrm{LC} / \mathrm{MS}$ & Faeces & [33] \\
\hline Prenol lipids & Triterpenoids & Decreased & IBD vs. control & $\mathrm{LC} / \mathrm{MS}$ & Faeces & [33] \\
\hline & \multirow{6}{*}{ Choline } & Decreased & CD vs. UC & ${ }^{1} \mathrm{H}-\mathrm{NMR}$ & Serum & [42] \\
\hline & & Decreased & IBD vs. control & ${ }^{1} \mathrm{H}-\mathrm{NMR}$ & Serum & [42] \\
\hline & & Decreased & IBD vs. control & ${ }^{1} \mathrm{H}-\mathrm{NMR}$ & Serum and plasma & [8] \\
\hline & & Decreased & IBD vs. control & ${ }^{1} \mathrm{H}-\mathrm{NMR}$ & Serum & [12] \\
\hline & & Decreased & IBD vs. control & ${ }^{1} \mathrm{H}-\mathrm{NMR}$ & Colonic mucosa & [15] \\
\hline & & Decreased & $\begin{array}{l}\text { Active } C D \text { vs. } \\
\text { remission } C D\end{array}$ & ${ }^{1} \mathrm{H}-\mathrm{NMR}$ & Colonic mucosa & [15] \\
\hline
\end{tabular}

Lai and colleagues found that CD patients exhibit decreased levels of sphingosine 1-phosphate (d16:1) in contrast to healthy controls [23]. This metabolite participates in inflammatory responses, as well as regulatory activities in several biological processes [70]. A study performed by Suh and colleagues, in which they determined sphingolipids profiles and the gene expression related to sphingosine 1-phosphate in an IBD cohort, demonstrated increased transcriptomic signatures in patients with active IBD in comparison to normal transcriptomic levels in IBD patients with remission. In addition, increased amounts of pro-apoptotic and pro-inflammatory sphingolipids were also found in this study [71]. Regarding the levels of these metabolites specifically in the intestinal tissue, Balasubramanian and colleagues found decreased levels of glycerophosphorylcholine, a glycerophospholipid that is part of the cell membrane, in colonic mucosa of IBD patients in comparison to the control group. This study reflects that inflammation affects mucosal cell membranes composition [15].

Regarding glycerolipids, the levels of glycerol have also been differentially detected in IBD patients. In fact, Scoville and colleagues found decreased levels of glycerol in serum samples of CD patients in comparison with healthy controls [10]. In addition, Marchesi and colleagues found increased glycerol levels in faecal samples of CD compared with UC patients and control subjects [13]. Finally, Franzosa and colleagues detected decreased levels of triacylglicerols and prenol lipids such as triterpenoids in faecal samples of IBD subjects when compared to its relative controls, contributing to the perturbations of lipid metabolism in the IBD pathology [33]. Nevertheless, given the scarce number of studies analysing these type of lipid metabolites, further studies are needed in order to better characterize their levels in these patients, since the lipid metabolism plays a key role in this pathology, and it is very probable that one of these lipid metabolites might become an interesting biomarker for IBD patients.

\section{Amino Acids}

Amino acids are defined as organic substances that contain both amino and acid groups. Although numerous amino acids have been described so far, only 20 serve as building blocks for protein synthesis. Those which constitute proteins are classified as protein amino acids, while those which do not constitute polypeptidic chains are classified as nonprotein amino acids [72]. In Table 5, we summarize all the studies that have demonstrated differential levels of amino acids in IBD patients specifying the type of sample and the technique used in each study. 
Table 5. Differential abundance of amino acids in IBD patients. Crohn's disease (CD), ulcerative colitis (UC), predominantly ileal CD (ICD), ultra-high performance liquid chromatography/tandem mass spectroscopy (UPLC-MS/MS), proton nuclear magnetic resonance $\left({ }^{1} \mathrm{H}-\mathrm{NMR}\right)$, liquid chromatography/mass spectrometry (LC/MS), ion cyclotron resonance Fourier transform mass spectrometry (ICR-FT/MS).

\begin{tabular}{|c|c|c|c|c|c|}
\hline Metabolite & Alteration & Patients & Technique & Sample & Reference \\
\hline 5-Hydroxy-L-tryptophan & Decreased & Active $C D$ and inactive $C D$ vs. control & $\mathrm{LC} / \mathrm{MS}$ & Serum & [23] \\
\hline \multirow{2}{*}{ Tryptophan } & Increased & UC vs. control & ${ }^{1} \mathrm{H}-\mathrm{NMR}$ & Urine & [8] \\
\hline & Increased & ICD vs. control & ICR-FT/MS & Faecal & [26] \\
\hline Indole-3-propionic acid & Decreased & Active $C D$ and inactive $C D$ vs. control & LC/MS & Serum & [23] \\
\hline Indole-3-acrylic acid & Decreased & Active $C D$ and inactive $C D$ vs. control & LC/MS & Serum & [23] \\
\hline 3-Methylindole & Decreased & Active $\mathrm{CD}$ and inactive $\mathrm{CD}$ vs. control & $\mathrm{LC} / \mathrm{MS}$ & Serum & [23] \\
\hline \multirow{4}{*}{ Phenylalanine } & Increased & ICD vs. control & ICR-FT/MS & Faeces & [26] \\
\hline & Increased & IBD vs. control & ${ }^{1} \mathrm{H}-\mathrm{NMR}$ & Faeces & [39] \\
\hline & Decreased & Active $C D$ and inactive $C D$ vs. control & $\mathrm{LC} / \mathrm{MS}$ & Serum & [23] \\
\hline & Increased & $\begin{array}{c}\text { IBD vs. control } \\
\text { Active IBD vs. remission IBD }\end{array}$ & ${ }^{1} \mathrm{H}-\mathrm{NMR}$ & Serum & [12] \\
\hline Ergothioneine & Decreased & Active $C D$ and inactive $C D$ vs. control & $\mathrm{LC} / \mathrm{MS}$ & Serum & [23] \\
\hline \multirow{2}{*}{ Histidine } & Decreased & IBD vs. control & ${ }^{1} \mathrm{H}-\mathrm{NMR}$ & Urine & [9] \\
\hline & Decreased & IBD vs. control & ${ }^{1} \mathrm{H}-\mathrm{NMR}$ & Serum & [12] \\
\hline \multirow{3}{*}{ Tyrosine } & Decreased & IBD vs. control & ${ }^{1} \mathrm{H}-\mathrm{NMR}$ & Serum and Plasma & [8] \\
\hline & Increased & IBD vs. control & ${ }^{1} \mathrm{H}-\mathrm{NMR}$ & Faeces & [13] \\
\hline & Increased & IBD vs. control & ${ }^{1} \mathrm{H}-\mathrm{NMR}$ & Faeces & [39] \\
\hline Dopaquinone & Increased & CD vs. control & ICR-FT/MS & Faeces & [26] \\
\hline \multirow{5}{*}{ Leucine } & Decreased & $\begin{array}{l}\text { CD vs. control } \\
\text { CD vs. UC }\end{array}$ & UPLC-MS/MS & Serum & [10] \\
\hline & Increased & $\begin{array}{c}\text { IBD vs. control } \\
\text { Active UC vs. inactive UC and control }\end{array}$ & ${ }^{1} \mathrm{H}-\mathrm{NMR}$ & Faeces & [39] \\
\hline & Increased & IBD vs. control & ${ }^{1} \mathrm{H}-\mathrm{NMR}$ & Serum & [12] \\
\hline & Increased & IBD vs. control & ${ }^{1} \mathrm{H}-\mathrm{NMR}$ & Faeces & [13] \\
\hline & Decreased & $\begin{array}{l}\text { IBD vs. control } \\
\text { Active } C D \text { vs. remission } C D\end{array}$ & ${ }^{1} \mathrm{H}-\mathrm{NMR}$ & Intestinal Biopsies & [15] \\
\hline \multirow{6}{*}{ Isoleucine } & Decreased & IBD vs. control & ${ }^{1} \mathrm{H}-\mathrm{NMR}$ & Serum & [42] \\
\hline & Increased & $\begin{array}{c}\text { IBD vs. control } \\
\text { Active UC vs. inactive UC and control }\end{array}$ & ${ }^{1} \mathrm{H}-\mathrm{NMR}$ & Faeces & [39] \\
\hline & Increased & IBD vs. control & ${ }^{1} \mathrm{H}-\mathrm{NMR}$ & Serum and Plasma & [8] \\
\hline & Increased & IBD vs. control & ${ }^{1} \mathrm{H}-\mathrm{NMR}$ & Serum & [12] \\
\hline & Increased & IBD vs. control & ${ }^{1} \mathrm{H}-\mathrm{NMR}$ & Faeces & [13] \\
\hline & Decreased & $\begin{array}{l}\text { IBD vs. control } \\
\text { Active CD vs. remission CD }\end{array}$ & ${ }^{1} \mathrm{H}-\mathrm{NMR}$ & Intestinal Biopsies & [15] \\
\hline \multirow{5}{*}{ Valine } & Decreased & $\begin{array}{l}\text { CD vs. control } \\
\text { CD vs. UC }\end{array}$ & UPLC-MS/MS & Serum & [10] \\
\hline & Increased & $\begin{array}{c}\text { IBD vs. control } \\
\text { Active UC vs. inactive UC and control }\end{array}$ & ${ }^{1} \mathrm{H}-\mathrm{NMR}$ & Faeces & [39] \\
\hline & Decreased & IBD vs. control & ${ }^{1} \mathrm{H}-\mathrm{NMR}$ & Serum and Plasma & [8] \\
\hline & Increased & IBD vs. control & ${ }^{1} \mathrm{H}-\mathrm{NMR}$ & Faeces & [13] \\
\hline & Decreased & $\begin{array}{c}\text { IBD vs. control } \\
\text { Active } C D \text { vs. remission } C D\end{array}$ & ${ }^{1} \mathrm{H}-\mathrm{NMR}$ & Intestinal Biopsies & [15] \\
\hline \multirow{2}{*}{ Glutamine } & Decreased & $\begin{array}{l}\text { CD vs. control } \\
\text { CD vs. UC }\end{array}$ & UPLC-MS/MS & Serum & [10] \\
\hline & Decreased & IBD vs. control & ${ }^{1} \mathrm{H}-\mathrm{NMR}$ & Intestinal Biopsies & [15] \\
\hline
\end{tabular}


Table 5. Cont.

\begin{tabular}{|c|c|c|c|c|c|}
\hline Metabolite & Alteration & Patients & Technique & Sample & Reference \\
\hline \multirow{6}{*}{ Alanine } & Decreased & IBD vs. control & ${ }^{1} \mathrm{H}-\mathrm{NMR}$ & Serum & {$[42]$} \\
\hline & Increased & IBD vs. control & ${ }^{1} \mathrm{H}-\mathrm{NMR}$ & Faeces & [13] \\
\hline & Increased & CD vs. UC & ${ }^{1} \mathrm{H}-\mathrm{NMR}$ & Serum & {$[12]$} \\
\hline & Increased & Active IBD vs. remission IBD & ${ }^{1} \mathrm{H}-\mathrm{NMR}$ & Urine & [12] \\
\hline & Increased & $\begin{array}{c}\text { IBD vs. control } \\
\text { Active UC vs. inactive UC and control }\end{array}$ & ${ }^{1} \mathrm{H}-\mathrm{NMR}$ & Faeces & {$[39]$} \\
\hline & Decreased & IBD vs. control & ${ }^{1} \mathrm{H}-\mathrm{NMR}$ & Intestinal Biopsies & [15] \\
\hline \multirow{6}{*}{ Lysine } & Decreased & CD vs. control & UPLC-MS/MS & Serum & [10] \\
\hline & Increased & IBD vs. control & ${ }^{1} \mathrm{H}-\mathrm{NMR}$ & Serum and Plasma & [8] \\
\hline & Decreased & IBD vs. control & ${ }^{1} \mathrm{H}-\mathrm{NMR}$ & Urine & [9] \\
\hline & Increased & IBD vs. control & ${ }^{1} \mathrm{H}-\mathrm{NMR}$ & Faeces & {$[13]$} \\
\hline & \multirow{2}{*}{ Increased } & IBD vs. control & \multirow{2}{*}{${ }^{1} \mathrm{H}-\mathrm{NMR}$} & \multirow{2}{*}{ Faeces } & \multirow{2}{*}[39]{} \\
\hline & & Active UC vs. inactive UC and control & & & \\
\hline Glycylproline & Increased & UC vs. control & ${ }^{1} \mathrm{H}-\mathrm{NMR}$ & Urine & [8] \\
\hline \multirow{2}{*}{ Arginine } & Decreased & CD vs. control & UPLC-MS/MS & Serum & {$[10]$} \\
\hline & Increased & IBD vs. control & ${ }^{1} \mathrm{H}-\mathrm{NMR}$ & Serum and Plasma & {$[8]$} \\
\hline Ornithine & Decreased & CD vs. control & ${ }^{1} \mathrm{H}-\mathrm{NMR}$ & Serum and Plasma & [8] \\
\hline Methionine & Increased & IBD vs. control & ${ }^{1} \mathrm{H}-\mathrm{NMR}$ & Serum and Plasma & {$[8]$} \\
\hline \multirow[t]{2}{*}{ Serine } & Decreased & $\begin{array}{l}\text { CD vs. control } \\
\text { CD vs. UC }\end{array}$ & UPLC-MS/MS & Serum & {$[10]$} \\
\hline & Decreased & IBD vs. control & ${ }^{1} \mathrm{H}-\mathrm{NMR}$ & Serum and Plasma & [8] \\
\hline \multirow{5}{*}{ Glycine } & Increased & IBD vs. control & ${ }^{1} \mathrm{H}-\mathrm{NMR}$ & Serum and Plasma & {$[8]$} \\
\hline & Increased & IBD vs. control & ${ }^{1} \mathrm{H}-\mathrm{NMR}$ & Serum & {$[12]$} \\
\hline & Increased & Active IBD vs. remission IBD & ${ }^{1} \mathrm{H}-\mathrm{NMR}$ & Urine & {$[12]$} \\
\hline & Decreased & Remission IBD vs. control & ${ }^{1} \mathrm{H}-\mathrm{NMR}$ & Urine & {$[12]$} \\
\hline & Increased & IBD vs. control & ${ }^{1} \mathrm{H}-\mathrm{NMR}$ & Faeces & {$[39]$} \\
\hline \multirow{2}{*}{ Asparagine } & Decreased & IBD vs. control & ${ }^{1} \mathrm{H}-\mathrm{NMR}$ & Urine & [9] \\
\hline & Increased & IBD vs. control & ${ }^{1} \mathrm{H}-\mathrm{NMR}$ & Faeces & {$[13]$} \\
\hline Aspartic acid & Increased & IBD vs. control & ${ }^{1} \mathrm{H}-\mathrm{NMR}$ & Faeces & {$[13]$} \\
\hline \multirow{2}{*}{ Glutamate } & Increased & IBD vs. control & ${ }^{1} \mathrm{H}-\mathrm{NMR}$ & Faeces & {$[13]$} \\
\hline & Decreased & IBD vs. control & ${ }^{1} \mathrm{H}-\mathrm{NMR}$ & Intestinal Biopsies & {$[15]$} \\
\hline Proline & Increased & IBD vs. control & ${ }^{1} \mathrm{H}-\mathrm{NMR}$ & Serum and Plasma & {$[8]$} \\
\hline \multirow{2}{*}{ Taurine } & Decreased & $\begin{array}{c}\text { IBD vs. control } \\
\text { Remission IBD vs. control }\end{array}$ & ${ }^{1} \mathrm{H}-\mathrm{NMR}$ & Urine & {$[12]$} \\
\hline & Increased & Active UC vs. inactive UC and control & ${ }^{1} \mathrm{H}-\mathrm{NMR}$ & Faeces & {$[39]$} \\
\hline
\end{tabular}

Firstly, it is important to take into account that due to inflammation, the epithelial barrier protection is disrupted leading to the malabsorption of nutrients in the gut and resulting in increased levels of amino acids in faeces of IBD patients [13,39]. Indeed, numerous studies using faecal samples confirmed this premise, since they reported increased levels of amino acid in IBD patients [13,26,39]. For instance, Bjerrum and colleagues reported increased levels of branched-chain amino acids such as isoleucine, leucine and valine, as well as other amino acids such as alanine, lysine, tyrosine in faecal samples of IBD patients compared to its relative controls [39]. On the other hand, as many studies conclude, the concentration of several amino acids in serum samples is usually decreased in these patients $[10,23,42]$. This difference depending on the type of the sample analysed demonstrates that patients suffering IBD exhibit an intensified catabolism of proteins 
as well as decreased absorption of amino acids in the gut due to inflammation and increased intestinal permeability [42]. Furthermore, it is important to consider that these patients show a decrease in the gut microbiome taxonomic diversity in comparison to healthy controls [33,73]. Most studies have reported changes in microbiota of IBD patients correspond with altered pathways and metabolites due to the fact that gut microorganisms are responsible of transforming dietary products into essential compounds for our metabolism [33,74-76]. Indeed, amino acids and their derivatives are the most common affected metabolites in this context. These compounds usually constitute ligands of transcription factors or certain receptors playing an important role in the inflammatory process and regulating the immune response [23].

Tryptophan is an essential amino acid whose levels are disturbed in IBD patients. In fact, Jansson and colleagues found increased levels of this amino acid in faecal samples of ICD subjects compared with controls [26]. In line with this, Schicho and colleagues used urine samples, and they also found increased levels of tryptophan in the UC cohort [8]. Of interest, Nikolaus and colleagues reported decreased levels of this amino acid in serum of IBD patients [77]. These results shed light to the importance of specifying the type of sample used to undergo the metabolomic analysis. In the case of urine and faecal samples, it is important to take into account that external factors such as dietary intake may influence in the variability of the obtained results, and they cannot exactly be correlated with the pathology [8].

Besides from tryptophan itself, more recent metabolomic analyses have revealed alterations in derivatives from tryptophan metabolism. Indeed, the study performed by Lai and colleagues showed disturbances in indolic derivatives, compounds that are produced from tryptophan by commensal microbiota. Specifically, they reported decreased levels of indole-3-propionic acid and indole-3-acrylic acid, while increased levels of 3-methylindole in CD patients [23]. In this sense, it is well known that commensal microbiota produce tryptophan decarboxylases that convert tryptophan into tryptamine and indole derivatives among others [78]. Such indole derivatives are known to bind aryl hydrocarbon receptor and stimulate IL-10 activity, an anti-inflammatory cytokine that inhibits the gene expression of the proinflammatory cytokine TNF- $\alpha[79,80]$. In the case of indole-3-acrylic acid, this metabolite binds pregnane $X$ receptor and stimulates the gene expression of mucin 2 , a structural protein from the intestinal epithelial barrier [81]. Hence, the decreased levels of these indole derivatives might be associated with the chronic inflammation observed in these patients. In addition, decreased amounts of 5-hydroxy-L-tryptophan (5-HTP) have been reported in the serum of CD patients [23], which affects serotonin levels triggering negative effects on intestinal permeability $[82,83]$.

Another amino acid disturbed in IBD patients is phenylalanine. Nevertheless, levels of this amino acid are still an open question that must be addressed. On the one hand, according to the study performed by Lai and colleagues, phenylalanine was decreased in serum of $\mathrm{CD}$ patients in comparison to controls. Moreover, Bjerrum and colleagues and Jansson and colleagues found increased levels of phenylalanine but, in this case, in faecal samples of IBD patients. These results might be explained due to the fact that phenylalanine has an anti-inflammatory role, since it inhibits TNF- $\alpha$ production and enhances immune responses [84]. On the other hand, Dawiskiba and colleagues found increased levels of phenylalanine in serum of active IBD patients when compared to controls and IBD remission patients. In this case, the authors state that immune response inhibits phenylalanine-4-hydroxylase activity, the enzyme responsible of hydrolysing phenylalanine into tyrosine [12]. Altogether, additional studies are needed in order to clarify the exact levels of this amino acid in IBD patients.

Histidine metabolism has also been found perturbed in the metabolomic analysis performed by Lai and colleagues. In fact, ergothioneine, a histidine derivative converted by microbiota or obtained from diet, was found in lower levels in serum samples of CD patients [23]. This metabolite is an antioxidant and neuroprotective agent, which defends cells from mitochondrial DNA damage and lipid peroxidation [85]. Reduced 
levels of ergothioneine might be associated with lack or impairment of its transporter, the organic cation/carnitine transporter 1 (OCTN1), which has also been associated to other inflammatory pathologies such as rheumatoid arthritis [86,87]. Hence, ergothioneine seems to be a potential biomarker to distinguish between $\mathrm{CD}$ and $\mathrm{UC}$, since its transporter is only expressed in small intestine [23]. In addition, Stephens and colleagues also found decreased levels of histidine, as well as lysine and asparagine, in urine samples of IBD patients in comparison with control individuals [9], and Dawiskiba and colleagues also found lower levels of histidine in serum samples of IBD patients [12].

The study performed by Jansson and colleagues found alterations also in the tyrosine metabolic pathway. They found that the metabolite dopaquinone was increased in faecal samples of CD patients in comparison to healthy controls. Dopaquinone is an intermediate of melanin formation, which comes from the oxidation of levodopa (L-DOPA) and, in turn, tyrosine [26]. In addition, other studies have demonstrated increased levels of L-DOPA in patients suffering IBD, another intermediate of this metabolite [88]. Unfortunately, there is not enough evidence to affirm that tyrosine pathway is involved or not in the pathogenesis of CD. Nevertheless, similar alterations have also been reported by other studies, which described an increase in the transcription of tyrosine metabolism genes in mononuclear cells from patients suffering CD [89].

On the other hand, Schicho and colleagues performed a metabolomic analysis using both plasma and serum samples, and they reported increased levels of isoleucine in serum samples from IBD patients in comparison to healthy subjects [8]. When using plasma samples, they found increased levels of lysine while reduced levels of valine and tyrosine. In both serum and plasma, they found decreased levels of ornithine, as well as urea in CD patients, and increased levels of arginine and methionine. Given the fact that most of them are intermediates of the urea cycle, authors state that IBD-related pathologies affect the urea cycle [8]. Additionally, some other studies also determined that there is a relationship between UC and increased levels of arginine [90].

In the specific case of glycine, it has been reported that there are increased levels of this amino acid in faecal [39] and urine samples [12] of IBD patients compared with healthy controls. It is important to consider that this amino acid plays a key role in the regulation of the inflammation [12]. When it binds to glycine-gated chloride channels, it inhibits the activation of immune cells such as neutrophils and macrophages, thus playing a cytoprotective and anti-inflammatory role [91].

Different levels of amino acids have also been reported specifically in intestinal mucosa. Indeed, Balasubramanian and colleagues revealed lower levels of the amino acids isoleucine, leucine, valine, glutamine, glutamate and alanine in colonic mucosa of IBD patients compared with healthy subjects [15]. The conversion of glutamine to alanine provides to the intestinal mucosa about one third of the required energy to accomplish the metabolic demand [92]. In this conversion, an amide group is formed, which is essential to synthetize membrane components of glycoproteins and amino sugars such as hexosamines [93]. Glutamine is also strictly related with the immune response, because it avoids bacterial attachment to mucosal cells by keeping IgA levels [94]. It also regulates inflammation by modulating IL-8 and TNF- $\alpha$ levels [15].

Of interest, Scoville and colleagues reported for the first time a set of amino acids that might be promising biomarkers in order to distinguish between CD and UC patients. In this study, authors reported decreased levels of amino acids such as leucine, lysine, valine, arginine, glutamine and serine in the serum of CD subjects when compared to its relative controls. In addition, they achieved interesting results, since they found that leucine, valine, serine and glutamine were even more reduced in CD patients than in UC patients and that there were no differences in the amino acid levels between UC and controls [10]. Moreover, Dawiskiba and colleagues found significant differences in alanine serum concentration between CD and UC patients [12]. Therefore, the specific analysis of these amino acids could help the complicated diagnosis between the two most common IBD pathologies. 
The utility of the amino acids as biomarkers has been even expanded to evaluate the clinical state of IBD patients. In this sense, levels of branched-chain amino acids (isoleucine, leucine and valine) were discriminative between patients with active CD in comparison with patients in remission [15]. This last observation points to these amino acids as promising biomarkers in order to evaluate the disease activity of CD patients. Taking everything together, it is clear that amino acids might be used as promising biomarkers in order to diagnose the specific IBD suffered by one patient and even analyse the specific clinical disease activity.

\section{Food Components and Xenobiotics}

The metabolomic analysis in IBD patients have also identified a huge diversity of xenobiotic compounds and their related metabolites, which are differentially present in these patients. The concept of xenobiotic comprises all the chemical substances found within an organism, which are foreign to the body or to an ecological system. These chemical products include plant constituents, cosmetics, drugs, food additives, industrial chemicals and environmental pollutants, and they access the organisms through several ways such as the air, diet, drinking water, lifestyle or drug administration [95]. Given the importance of the environment in both the onset and the evolution of IBD, the xenobiotics play a pivotal role in this pathology and might provide essential information regarding the molecular mechanisms involved in this disease. Nevertheless, to what extent they play beneficial or harmful effects in this pathology remains poorly characterized. Therefore, in this section, we describe the xenobiotics, which have been identified specifically in IBD patients so far, and we discuss whether they can be considered biomarkers or pharmacological targets.

The diet constitutes one of the most critical environmental factor with a huge impact on the composition of intestinal microbiota affecting the immune response [96]. In addition, given the introduction of the modern processed foods, the amount of xenobiotcs introduced in our body throughout our life is continuously increasing [97]. Indeed, it has been described that children with CD present changes in the gut microbiome and xenobiotic metabolism [98]. Given the fact that coffee, one of the most commonly consumed drinks, contains a wide range diversity of bioactive compounds such as caffeine, trigonelline, phenolic compounds, diterpenes and soluble fibre; the coffee-derived metabolites have also been analysed in IBD patients [99]. One example of a specific xenobiotic specifically found in these patients is the major caffeine metabolite called 5-acetylamino-6-amino-3methyluracil (AAMU). In fact, Lai and colleagues have recently reported that levels of AAMU are significantly increased in the serum of active CD compared with inactive CD patients and the control group. During the metabolism of caffeine, xanthine oxidoreductase catalyses paraxanthine to xanthine, which is oxidized in uric acid [100]. Interestingly, Neubauer and colleagues have recently analysed the levels of uric acid in serum of both UC and CD patients, and they reported significantly lower levels only in both active CD and active UC patients compared with control groups. In the same study, they also reported lower levels of free thiol status and total antioxidant status in both CD and UC patients [101].

A special consideration of the vitamin $\mathrm{D}$ metabolites needs to be addressed, since the vitamin D deficiency is more prevalent in patients with CD or UC than in non-IBD patients [102]. There is growing evidence that reduced serum levels of vitamin D are associated with an increased disease activity in IBD patients [103-105]. Furthermore, Limketkai and colleagues have recently expanded these observations, and they have reported that the reduced levels of serum vitamin D are observed once the IBD disease has been diagnosed and not before the diagnosis, which suggests that reduced levels of vitamin $\mathrm{D}$ are not the cause of the onset of the inflammation, but the chronic inflammation leads to lower levels of vitamin D [106]. Nevertheless, although the quantification of vitamin D is based on the determination of levels of total 25-hydroxyvitamin D (25OHD), other vitamin D metabolites such as 1,25OH2D and dihydroxycholecalciferol (24,25OH2D) are also of potential interest, since $25 \mathrm{OHD}$ is not the most biologically active metabolite [107]. In fact, 
the utility of serum 25OHD levels as biomarker for IBD patients is still not clear. In this line, Aksan and colleagues have recently reported a study in which they analysed the serum levels of 25OHD, vitamin-D-binding protein (VDBP), 1,25-dihydroxyvitamin D (1,25OHD) and dihydroxycholecalciferol $(24,25 \mathrm{OHD})$ in a cohort of IBD patients and demonstrated that serum total $25 \mathrm{OHD}$ was the only vitamin $\mathrm{D}$ metabolite without a correlation with the levels of inflammatory parameters. Hence, in this study, authors suggest that total 25OHD seems to be the best marker of vitamin D concentration in IBD patients regardless of the inflammatory status [108]. However, there are still several questions that still need an answer: Is the supplementation of vitamin D beneficial for IBD patients? Can the reduced levels of vitamin D trigger the inflammation or are these lower levels the consequence of the chronic inflammation observed in these patients? Do vitamin D levels correlate with the clinical activity of the disease? It is clear that, in spite of the huge number of studies analysing vitamin D levels in IBD patients, additional studies must be performed with the purpose to answer all these concerns.

Besides vitamin $\mathrm{D}$, accumulative evidence has demonstrated that IBD patients also present reduced levels of other vitamins such as vitamin B9 (folate) and vitamin B12 (cobalamin), whose deficiency causes a worsening in the clinical, biochemical and inflammatory status $[109,110]$. In line with this, Gioxari and colleagues have recently reproduced these observations in a cohort of Greek IBD patients where they reported a serum deficiency in vitamin D, B9 and B12 in 36.8, 18.4 and 5.7\% of patients, respectively. They also correlated these serum metabolite levels with clinical information and pointed to the serum vitamin profile as a complementary biomarker for the evaluation of the disease activity [111]. On the other hand, Weng and colleagues have recently reported that the levels of other vitamins compounds such as vitamin B2 (riboflavin) and nicotinate are significantly reduced in faecal samples from both UC and CD patients compared with healthy controls. In the same study, authors also correlated the metabolite levels with the abundance of intestinal microbiota, and they identified eight key species that were associated with 25(OH)D3, 3-hydroxyisovaleric acid, ascorbylstearate, glycolithocholic acid, nicotinate and putrescine. Moreover, they also showed a negative correlation between Clostridium clostridioforme and vitamin D levels, while Alcanivorax hongdengensi positively correlated with vitamin C [27]. It is important to take into account that this study reveals the direct influence of the intestinal microbiota in the metabolomics profiles.

Apart from metabolites derived from coffee and several vitamins, any food can be the source of different xenobiotics. For instance, Lai and colleagues have recently reported that the levels of pterosin E from root vegetables are significantly increased in the serum of both active and inactive $\mathrm{CD}$ patients compared with the control group [23]. In addition, Kestheli and colleagues compared the metabolomic signatures in urine samples from postoperative recurrent $\mathrm{CD}$ patients and $\mathrm{CD}$ patients in remission, and they reported increased levels of 1,6-anhydro-beta-D-Glucose (levoglucosan), an organic compound with a six-carbon ring structure formed after the pyrolysis of carbohydrates, and reduced levels of propylene glycol in recurrent CD patients. In addition, in this study, the authors also demonstrated that levoglucosan levels correlated with the presence of Bacteroidales and gammaproteobacteria, which strongly supports the direct relationship between the intestinal microbiota and the presence of xenobiotics in urine of IBD patients [112].

Altogether, given the scarce number of studies analysing the presence of xenobiotics in IBD patients and the huge diversity of these chemical compounds, future studies are needed in order to (a) detect key xenobiotics, which might be useful to identify environmental risk factors associated to this pathology, (b) find potential biomarkers or pharmacological targets for IBD patients, (c) confirm whether these differences are specific to IBD patients or are only due to differences in the lifestyle of the patients analysed so far, (d) validate the data already published in several cohort of IBD patients, (e) assess the efficacy of the pharmacological treatment. 


\section{Conclusions}

IBD is a chronic pathology whose aetiology is still not well known and the clinical use of biomarkers in order to diagnose this pathology or evaluate the disease activity is still scarce due to the lack of reliable biomarkers. Of interest, during the last years, metabolomics has bounced into IBD and has identified specific metabolomic profiles in these patients. Thanks to the identification of numerous metabolites differentially present in IBD patients, metabolomics has become an extremely useful technique in order to identify promising biomarkers that might provide better tools for both the diagnosis and the evaluation of this disease.

Interestingly, the metabolomic studies performed so far have identified a huge number of metabolites, whose levels are specifically different in IBD patients, involved in a wide range of metabolic pathways such as TCA cycle, $\beta$-oxidation, urea cycle, etc. The direct effect of intestinal inflammation on several metabolic pathways is widely assumed [113]. In this point, it is important to take into account that those metabolites are usually involved in molecular pathways implicated in the inflammatory response. Nevertheless, it is still not clear whether this metabolic alteration is a cause or a consequence of the chronic and persistent inflammation present in IBD patients. Although emerging studies suggest that these metabolic disturbances might appear as a result of an inflammatory scenario, further studies are needed in order to confirm this hypothesis.

One important aspect that needs to be considered is the type of biological sample used in the metabolomic analysis. During this review, we have detailed the kind of sample used in each study, since the levels of each metabolite can differ depending on the biological sample due to the microbial dysbiosis, impaired intestinal absorption or even pharmacological and surgical treatments of IBD patients. To date, most of the studies performed have analysed the metabolome specifically in non-invasive biological samples such as serum, plasma, urine and stool. Nevertheless, the analysis of the metabolomics profiles specifically in intestinal tissue of IBD patients would reflect the specific metabolic alterations in this tissue and might provide more specific information about possible biomarkers or even pharmacological targets. Therefore, despite the difficulty in obtaining intestinal tissues, future studies are needed in order to better elucidate the molecular mechanisms involved in the pathogenesis of IBD.

At this point, we would like to mention that one limitation of the metabolomics studies is the reduced number of IBD patients included. Hence, bigger cohort of patients must be studied in the next few years with the purpose of identifying specific metabolites that can be used in the clinics as biomarkers. In addition, one of the most pursued aims is to identify biomarkers that can predict whether an IBD patient will be a responder or a non-responder to one conventional therapy. Of interest, Ding and colleagues have recently reported a set of metabolites involving lipid, bile acid and amino acid pathways, which might contribute to predict the response to anti-TNF therapy [114]. This elegant study represents the starting point of a promising strategy in order to stablish some metabolites as predictors of the efficacy of the pharmacological treatment assigned to each IBD patient. Nevertheless, to achieve this ambitious goal, additional studies are required so as to confirm the potential capacity of those metabolites to predict the response of each IBD patient to a conventional therapy.

Finally, it is important to take into account that, despite the large number of metabolites identified so far, there is still a huge gap between the identification of these compounds and the knowledge of their specific role in IBD. Hence, future studies should integrate all the metabolomic profiles with other results derived from different omics. Thus, these studies would identify new biomarkers and molecular mechanisms involved in the pathogenesis of IBD.

Author Contributions: C.B., L.G.-F. and J.C.-R. wrote the original draft manuscript. C.B. and J.C.-R. critically reviewed the manuscript. All authors edited the final version of the manuscript. J.C.-R. obtained funding. All authors have read and agreed to the published version of the manuscript. 
Funding: This work was funded by CIBERehd [CB06/04/0071], CIBER-EHD 2016/ACCESS EHD16PI02, CIBEREHD Investigadores Noveles [EHD19PI05], Fundación para el Fomento de la Investigación Sanitaria y Biomédica de la Comunitat Valenciana [UGP-19-032], Ministerio de Ciencia, Innovación y Universidades [PID2019-108996RB-I00] and [PROMETEO/2018/141].

Institutional Review Board Statement: Not applicable.

Informed Consent Statement: Not applicable.

Data Availability Statement: Not applicable.

Conflicts of Interest: The authors declare no conflict of interest.

\section{References}

1. Neri, B.; Mossa, M.; Scucchi, L.; Sena, G.; Palmieri, G.; Biancone, L. Review Article: Histological Scores in Inflammatory Bowel Disease. J. Dig. Dis 2020. [CrossRef] [PubMed]

2. Kaplan, G.G.; Ng, S.C. Understanding and Preventing the Global Increase of Inflammatory Bowel Disease. Gastroenterology 2017, 152, 313-321.e2. [CrossRef]

3. Nishida, A.; Inoue, R.; Inatomi, O.; Bamba, S.; Naito, Y.; Andoh, A. Gut microbiota in the pathogenesis of inflammatory bowel disease. Clin. J. Gastroenterol. 2018, 11, 1-10. [CrossRef]

4. Peyrin-Biroulet, L.; Reinisch, W.; Colombel, J.F.; Mantzaris, G.J.; Kornbluth, A.; Diamond, R.; Rutgeerts, P.; Tang, L.K.; Cornillie, F.J.; Sandborn, W.J. Clinical disease activity, C-reactive protein normalisation and mucosal healing in Crohn's disease in the SONIC trial. Gut 2014, 63, 88-95. [CrossRef]

5. Chen, P.; Zhou, G.; Lin, J.; Li, L.; Zeng, Z.; Chen, M.; Zhang, S. Serum Biomarkers for Inflammatory Bowel Disease. Front. Med. 2020, 7, 123. [CrossRef] [PubMed]

6. Gallagher, K.; Catesson, A.; Griffin, J.L.; Holmes, E.; Williams, H.R.T. Metabolomic Analysis in Inflammatory Bowel Disease: A Systematic Review. J. Crohns Colitis 2020. [CrossRef]

7. Martinez-Reyes, I.; Chandel, N.S. Mitochondrial TCA cycle metabolites control physiology and disease. Nat. Commun. 2020, 11, 102. [CrossRef]

8. Schicho, R.; Shaykhutdinov, R.; Ngo, J.; Nazyrova, A.; Schneider, C.; Panaccione, R.; Kaplan, G.G.; Vogel, H.J.; Storr, M. Quantitative metabolomic profiling of serum, plasma, and urine by (1)H NMR spectroscopy discriminates between patients with inflammatory bowel disease and healthy individuals. J. Proteome Res. 2012, 11, 3344-3357. [CrossRef] [PubMed]

9. Stephens, N.S.; Siffledeen, J.; Su, X.; Murdoch, T.B.; Fedorak, R.N.; Slupsky, C.M. Urinary NMR metabolomic profiles discriminate inflammatory bowel disease from healthy. J. Crohns Colitis 2013, 7, e42-e48. [CrossRef]

10. Scoville, E.A.; Allaman, M.M.; Brown, C.T.; Motley, A.K.; Horst, S.N.; Williams, C.S.; Koyama, T.; Zhao, Z.; Adams, D.W.; Beaulieu, D.B.; et al. Alterations in Lipid, Amino Acid, and Energy Metabolism Distinguish Crohn's Disease from Ulcerative Colitis and Control Subjects by Serum Metabolomic Profiling. Metabolomics 2018, 14, 17. [CrossRef]

11. Alonso, A.; Julia, A.; Vinaixa, M.; Domenech, E.; Fernandez-Nebro, A.; Canete, J.D.; Ferrandiz, C.; Tornero, J.; Gisbert, J.P.; Nos, P.; et al. Urine metabolome profiling of immune-mediated inflammatory diseases. BMC Med. 2016, 14, 133. [CrossRef]

12. Dawiskiba, T.; Deja, S.; Mulak, A.; Zabek, A.; Jawien, E.; Pawelka, D.; Banasik, M.; Mastalerz-Migas, A.; Balcerzak, W.; Kaliszewski, K.; et al. Serum and urine metabolomic fingerprinting in diagnostics of inflammatory bowel diseases. World, J. Gastroenterol. 2014, 20, 163-174. [CrossRef]

13. Marchesi, J.R.; Holmes, E.; Khan, F.; Kochhar, S.; Scanlan, P.; Shanahan, F.; Wilson, I.D.; Wang, Y. Rapid and noninvasive metabonomic characterization of inflammatory bowel disease. J. Proteome Res. 2007, 6, 546-551. [CrossRef]

14. Martin, F.P.; Ezri, J.; Cominetti, O.; Da Silva, L.; Kussmann, M.; Godin, J.P.; Nydegger, A. Urinary Metabolic Phenotyping Reveals Differences in the Metabolic Status of Healthy and Inflammatory Bowel Disease (IBD) Children in Relation to Growth and Disease Activity. Int. J. Mol. Sci. 2016, 17, 1310. [CrossRef]

15. Balasubramanian, K.; Kumar, S.; Singh, R.R.; Sharma, U.; Ahuja, V.; Makharia, G.K.; Jagannathan, N.R. Metabolism of the colonic mucosa in patients with inflammatory bowel diseases: An in vitro proton magnetic resonance spectroscopy study. Magn. Reson. Imaging 2009, 27, 79-86. [CrossRef]

16. Ooi, M.; Nishiumi, S.; Yoshie, T.; Shiomi, Y.; Kohashi, M.; Fukunaga, K.; Nakamura, S.; Matsumoto, T.; Hatano, N.; Shinohara, M.; et al. GC/MS-based profiling of amino acids and TCA cycle-related molecules in ulcerative colitis. Inflamm. Res. 2011, 60, 831-840. [CrossRef]

17. Macias-Ceja, D.C.; Ortiz-Masia, D.; Salvador, P.; Gisbert-Ferrandiz, L.; Hernandez, C.; Hausmann, M.; Rogler, G.; Esplugues, J.V.; Hinojosa, J.; Alos, R.; et al. Succinate receptor mediates intestinal inflammation and fibrosis. Mucosal Immunol. 2019, 12, 178-187. [CrossRef] [PubMed]

18. Ortiz-Masia, D.; Gisbert-Ferrandiz, L.; Bauset, C.; Coll, S.; Mamie, C.; Scharl, M.; Esplugues, J.V.; Alos, R.; Navarro, F.; Cosin-Roger, J.; et al. Succinate Activates EMT in Intestinal Epithelial Cells through SUCNR1: A Novel Protagonist in Fistula Development. Cells 2020, 9, 1104. [CrossRef] [PubMed]

19. Amatullah, H.; Jeffrey, K.L. Epigenome-metabolome-microbiome axis in health and IBD. Curr. Opin. Microbiol. 2020, 56, 97-108. [CrossRef] [PubMed] 
20. Bushman, F.D.; Conrad, M.; Ren, Y.; Zhao, C.; Gu, C.; Petucci, C.; Kim, M.S.; Abbas, A.; Downes, K.J.; Devas, N.; et al. Multi-omic Analysis of the Interaction between Clostridioides difficile Infection and Pediatric Inflammatory Bowel Disease. Cell Host Microbe 2020, 28, 422-433. e7. [CrossRef] [PubMed]

21. Zaidi, D.; Huynh, H.Q.; Carroll, M.W.; Mandal, R.; Wishart, D.S.; Wine, E. Gut Microenvironment and Bacterial Invasion in Paediatric Inflammatory Bowel Diseases. J. Pediatr. Gastroenterol. Nutr. 2020, 71, 624-632.

22. Fahy, E.; Cotter, D.; Sud, M.; Subramaniam, S. Lipid classification, structures and tools. Biochim. Biophys. Acta 2011, 1811, 637-647. [CrossRef]

23. Lai, Y.; Xue, J.; Liu, C.W.; Gao, B.; Chi, L.; Tu, P.; Lu, K.; Ru, H. Serum Metabolomics Identifies Altered Bioenergetics, Signaling Cascades in Parallel with Exposome Markers in Crohn's Disease. Molecules 2019, 24, 449. [CrossRef]

24. Daniluk, U.; Daniluk, J.; Kucharski, R.; Kowalczyk, T.; Pietrowska, K.; Samczuk, P.; Filimoniuk, A.; Kretowski, A.; Lebensztejn, D.; Ciborowski, M. Untargeted Metabolomics and Inflammatory Markers Profiling in Children With Crohn's Disease and Ulcerative Colitis-A Preliminary Study. Inflamm. Bowel Dis. 2019, 25, 1120-1128. [CrossRef] [PubMed]

25. Bjerrum, J.T.; Steenholdt, C.; Ainsworth, M.; Nielsen, O.H.; Reed, M.A.; Atkins, K.; Gunther, U.L.; Hao, F.; Wang, Y. Metabonomics uncovers a reversible proatherogenic lipid profile during infliximab therapy of inflammatory bowel disease. BMC Med. 2017, 15, 184. [CrossRef] [PubMed]

26. Jansson, J.; Willing, B.; Lucio, M.; Fekete, A.; Dicksved, J.; Halfvarson, J.; Tysk, C.; Schmitt-Kopplin, P. Metabolomics reveals metabolic biomarkers of Crohn's disease. PLoS ONE 2009, 4, e6386. [CrossRef] [PubMed]

27. Weng, Y.J.; Gan, H.Y.; Li, X.; Huang, Y.; Li, Z.C.; Deng, H.M.; Chen, S.Z.; Zhou, Y.; Wang, L.S.; Han, Y.P.; et al. Correlation of diet, microbiota and metabolite networks in inflammatory bowel disease. J. Dig. Dis. 2019, 20, 447-459. [CrossRef]

28. Lu, K.; Knutson, C.G.; Wishnok, J.S.; Fox, J.G.; Tannenbaum, S.R. Serum metabolomics in a Helicobacter hepaticus mouse model of inflammatory bowel disease reveal important changes in the microbiome, serum peptides, and intermediary metabolism. $J$. Proteome Res. 2012, 11, 4916-4926. [CrossRef] [PubMed]

29. Zuniga, J.; Cancino, M.; Medina, F.; Varela, P.; Vargas, R.; Tapia, G.; Videla, L.A.; Fernandez, V. N-3 PUFA supplementation triggers PPAR-alpha activation and PPAR-alpha/NF-kappaB interaction: Anti-inflammatory implications in liver ischemia-reperfusion injury. PLoS ONE 2011, 6, e28502. [CrossRef] [PubMed]

30. Liberato, M.V.; Nascimento, A.S.; Ayers, S.D.; Lin, J.Z.; Cvoro, A.; Silveira, R.L.; Martinez, L.; Souza, P.C.; Saidemberg, D.; Deng, T.; et al. Medium chain fatty acids are selective peroxisome proliferator activated receptor (PPAR) gamma activators and pan-PPAR partial agonists. PLoS ONE 2012, 7, e36297. [CrossRef]

31. Ramakers, J.D.; Mensink, R.P.; Schaart, G.; Plat, J. Arachidonic acid but not eicosapentaenoic acid (EPA) and oleic acid activates NF-kappaB and elevates ICAM-1 expression in Caco-2 cells. Lipids 2007, 42, 687-698. [CrossRef]

32. Sheibanie, A.F.; Yen, J.H.; Khayrullina, T.; Emig, F.; Zhang, M.; Tuma, R.; Ganea, D. The proinflammatory effect of prostaglandin E2 in experimental inflammatory bowel disease is mediated through the IL-23->IL-17 axis. J. Immunol. 2007, 178, 8138-8147. [CrossRef]

33. Franzosa, E.A.; Sirota-Madi, A.; Avila-Pacheco, J.; Fornelos, N.; Haiser, H.J.; Reinker, S.; Vatanen, T.; Hall, A.B.; Mallick, H.; McIver, L.J.; et al. Gut microbiome structure and metabolic activity in inflammatory bowel disease. Nat. Microbiol. 2019, 4, 293-305. [CrossRef]

34. Parada Venegas, D.; De la Fuente, M.K.; Landskron, G.; Gonzalez, M.J.; Quera, R.; Dijkstra, G.; Harmsen, H.J.M.; Faber, K.N.; Hermoso, M.A. Short Chain Fatty Acids (SCFAs)-Mediated Gut Epithelial and Immune Regulation and Its Relevance for Inflammatory Bowel Diseases. Front. Immunol. 2019, 10, 277. [CrossRef] [PubMed]

35. Frank, D.N.; St Amand, A.L.; Feldman, R.A.; Boedeker, E.C.; Harpaz, N.; Pace, N.R. Molecular-phylogenetic characterization of microbial community imbalances in human inflammatory bowel diseases. Proc. Natl. Acad. Sci. USA 2007, 104, 13780-13785. [CrossRef]

36. Sartor, R.B. Therapeutic correction of bacterial dysbiosis discovered by molecular techniques. Proc. Natl. Acad. Sci. USA 2008, 105, 16413-16414. [CrossRef]

37. Tedelind, S.; Westberg, F.; Kjerrulf, M.; Vidal, A. Anti-inflammatory properties of the short-chain fatty acids acetate and propionate: A study with relevance to inflammatory bowel disease. World J. Gastroenterol. 2007, 13, 2826-2832. [CrossRef] [PubMed]

38. Araki, Y.; Andoh, A.; Fujiyama, Y.; Itoh, A.; Bamba, T. In vitro alterations in fecal short chain fatty acids and organic anions induced by the destruction of intestinal microflora under hypotonic and aerobic conditions. Int. J. Mol. Med. 2002, 9, 627-631. [CrossRef] [PubMed]

39. Bjerrum, J.T.; Wang, Y.; Hao, F.; Coskun, M.; Ludwig, C.; Gunther, U.; Nielsen, O.H. Metabonomics of human fecal extracts characterize ulcerative colitis, Crohn's disease and healthy individuals. Metabolomics 2015, 11, 122-133. [CrossRef] [PubMed]

40. Esteve-Comas, M.; Ramirez, M.; Fernandez-Banares, F.; Abad-Lacruz, A.; Gil, A.; Cabre, E.; Gonzalez-Huix, F.; Moreno, J.; Humbert, P.; Guilera, M.; et al. Plasma polyunsaturated fatty acid pattern in active inflammatory bowel disease. Gut 1992, 33, 1365-1369. [CrossRef] [PubMed]

41. Desbois, A.P.; Smith, V.J. Antibacterial free fatty acids: Activities, mechanisms of action and biotechnological potential. Appl. Microbiol. Biotechnol. 2010, 85, 1629-1642. [CrossRef]

42. Williams, H.R.; Willsmore, J.D.; Cox, I.J.; Walker, D.G.; Cobbold, J.F.; Taylor-Robinson, S.D.; Orchard, T.R. Serum metabolic profiling in inflammatory bowel disease. Dig. Dis. Sci. 2012, 57, 2157-2165. [CrossRef] 
43. Mora, J.R.; Iwata, M.; Von Andrian, U.H. Vitamin effects on the immune system: Vitamins A and D take centre stage. Nat. Rev. Immunol. 2008, 8, 685-698. [CrossRef] [PubMed]

44. Chatterjee, B.; Echchgadda, I.; Song, C.S. Vitamin D receptor regulation of the steroid/bile acid sulfotransferase SULT2A1. Methods Enzymol. 2005, 400, 165-191.

45. Yoneno, K.; Hisamatsu, T.; Shimamura, K.; Kamada, N.; Ichikawa, R.; Kitazume, M.T.; Mori, M.; Uo, M.; Namikawa, Y.; Matsuoka, K.; et al. TGR5 signalling inhibits the production of pro-inflammatory cytokines by in vitro differentiated inflammatory and intestinal macrophages in Crohn's disease. Immunology 2013, 139, 19-29. [CrossRef] [PubMed]

46. Maruyama, T.; Miyamoto, Y.; Nakamura, T.; Tamai, Y.; Okada, H.; Sugiyama, E.; Nakamura, T.; Itadani, H.; Tanaka, K. Identification of membrane-type receptor for bile acids (M-BAR). Biochem. Biophys. Res. Commun. 2002, 298, 714-719. [CrossRef]

47. Lapidus, A.; Akerlund, J.E.; Einarsson, C. Gallbladder bile composition in patients with Crohn 's disease. World J. Gastroenterol 2006, 12, 70-74. [CrossRef]

48. Querfeld, U.; Ong, J.M.; Prehn, J.; Carty, J.; Saffari, B.; Jordan, S.C.; Kern, P.A. Effects of cytokines on the production of lipoprotein lipase in cultured human macrophages. J. Lipid Res. 1990, 31, 1379-1386. [CrossRef]

49. Friedman, G.; Barak, V.; Chajek-Shaul, T.; Etienne, J.; Treves, A.J.; Stein, O.; Stein, Y. Recombinant human interleukin-1 suppresses lipoprotein lipase activity, but not expression of lipoprotein lipase mRNA in mesenchymal rat heart cell cultures. Biochim. Biophys. Acta 1991, 1089, 83-87. [CrossRef]

50. Van der Vorst, E.P.C. High-Density Lipoproteins and Apolipoprotein A1. Subcell Biochem. 2020, 94, $399-420$.

51. Hyka, N.; Dayer, J.M.; Modoux, C.; Kohno, T.; Edwards, C.K.; Roux-Lombard, P.; Burger, D. Apolipoprotein A-I inhibits the production of interleukin-1beta and tumor necrosis factor-alpha by blocking contact-mediated activation of monocytes by $\mathrm{T}$ lymphocytes. Blood 2001, 97, 2381-2389. [CrossRef]

52. Levy, E.; Rizwan, Y.; Thibault, L.; Lepage, G.; Brunet, S.; Bouthillier, L.; Seidman, E. Altered lipid profile, lipoprotein composition, and oxidant and antioxidant status in pediatric Crohn disease. Am. J. Clin. Nutr 2000, 71, 807-815. [CrossRef] [PubMed]

53. Ripolles Piquer, B.; Nazih, H.; Bourreille, A.; Segain, J.P.; Huvelin, J.M.; Galmiche, J.P.; Bard, J.M. Altered lipid, apolipoprotein, and lipoprotein profiles in inflammatory bowel disease: Consequences on the cholesterol efflux capacity of serum using Fu5AH cell system. Metabolism 2006, 55, 980-988. [CrossRef] [PubMed]

54. Abdel Hadi, L.; Di Vito, C.; Riboni, L. Fostering Inflammatory Bowel Disease: Sphingolipid Strategies to Join Forces. Mediators Inflamm. 2016, 2016, 3827684. [CrossRef] [PubMed]

55. Braun, A.; Treede, I.; Gotthardt, D.; Tietje, A.; Zahn, A.; Ruhwald, R.; Schoenfeld, U.; Welsch, T.; Kienle, P.; Erben, G.; et al. Alterations of phospholipid concentration and species composition of the intestinal mucus barrier in ulcerative colitis: A clue to pathogenesis. Inflamm. Bowel Dis. 2009, 15, 1705-1720. [CrossRef] [PubMed]

56. Qi, Y.; Jiang, C.; Tanaka, N.; Krausz, K.W.; Brocker, C.N.; Fang, Z.Z.; Bredell, B.X.; Shah, Y.M.; Gonzalez, F.J. PPARalpha-dependent exacerbation of experimental colitis by the hypolipidemic drug fenofibrate. Am. J. Physiol. Gastrointest Liver Physiol. 2014, 307, G564-G573. [CrossRef] [PubMed]

57. Michel, V.; Yuan, Z.; Ramsubir, S.; Bakovic, M. Choline transport for phospholipid synthesis. Exp. Biol. Med. 2006, 231, 490-504. [CrossRef]

58. Ueland, P.M. Choline and betaine in health and disease. J. Inherit. Metab. Dis. 2011, 34, 3-15. [CrossRef] [PubMed]

59. Buchman, A.L.; Dubin, M.D.; Moukarzel, A.A.; Jenden, D.J.; Roch, M.; Rice, K.M.; Gornbein, J.; Ament, M.E. Choline deficiency: A cause of hepatic steatosis during parenteral nutrition that can be reversed with intravenous choline supplementation. Hepatology 1995, 22, 1399-1403.

60. Zeisel, S.H. Is there a new component of the Mediterranean diet that reduces inflammation? Am. J. Clin. Nutr. 2008, 87, 277-278. [CrossRef]

61. Niculescu, M.D.; Da Costa, K.A.; Fischer, L.M.; Zeisel, S.H. Lymphocyte gene expression in subjects fed a low-choline diet differs between those who develop organ dysfunction and those who do not. Am. J. Clin. Nutr. 2007, 86, 230-239. [CrossRef] [PubMed]

62. Zeisel, S.H.; Blusztajn, J.K. Choline and human nutrition. Annu. Rev. Nutr. 1994, 14, 269-296. [CrossRef] [PubMed]

63. Nassif, A.; Longo, W.E.; Mazuski, J.E.; Vernava, A.M.; Kaminski, D.L. Role of cytokines and platelet-activating factor in inflammatory bowel disease. Implications for therapy. Dis. Colon Rectum 1996, 39, 217-223. [CrossRef] [PubMed]

64. Filimoniuk, A.; Daniluk, U.; Samczuk, P.; Wasilewska, N.; Jakimiec, P.; Kucharska, M.; Lebensztejn, D.M.; Ciborowski, M. Metabolomic profiling in children with inflammatory bowel disease. Adv. Med. Sci. 2020, 65, 65-70. [CrossRef] [PubMed]

65. Filimoniuk, A.; Blachnio-Zabielska, A.; Imierska, M.; Lebensztejn, D.M.; Daniluk, U. Sphingolipid Analysis Indicate Lactosylceramide as a Potential Biomarker of Inflammatory Bowel Disease in Children. Biomolecules 2020, 10, 1083. [CrossRef] [PubMed]

66. Stevens, C.R.; Oberholzer, V.G.; Walker-Smith, J.A.; Phillips, A.D. Lactosylceramide in inflammatory bowel disease: A biochemical study. Gut 1988, 29, 580-587. [CrossRef] [PubMed]

67. Bhunia, A.K.; Arai, T.; Bulkley, G.; Chatterjee, S. Lactosylceramide mediates tumor necrosis factor-alpha-induced intercellular adhesion molecule-1 (ICAM-1) expression and the adhesion of neutrophil in human umbilical vein endothelial cells. J. Biol. Chem. 1998, 273, 34349-34357. [CrossRef]

68. Arai, T.; Bhunia, A.K.; Chatterjee, S.; Bulkley, G.B. Lactosylceramide stimulates human neutrophils to upregulate Mac-1, adhere to endothelium, and generate reactive oxygen metabolites in vitro. Circ. Res. 1998, 82, 540-547. [CrossRef] 
69. Nakamura, H.; Moriyama, Y.; Watanabe, K.; Tomizawa, S.; Yamazaki, R.; Takahashi, H.; Murayama, T. Lactosylceramide-Induced Phosphorylation Signaling to Group IVA Phospholipase A2 via Reactive Oxygen Species in Tumor Necrosis Factor-alpha-Treated Cells. J. Cell Biochem. 2017, 118, 4370-4382. [CrossRef]

70. Maceyka, M.; Harikumar, K.B.; Milstien, S.; Spiegel, S. Sphingosine-1-phosphate signaling and its role in disease. Trends Cell Biol. 2012, 22, 50-60. [CrossRef]

71. Suh, J.H.; Degagne, E.; Gleghorn, E.E.; Setty, M.; Rodriguez, A.; Park, K.T.; Verstraete, S.G.; Heyman, M.B.; Patel, A.S.; Irek, M.; et al. Sphingosine-1-Phosphate Signaling and Metabolism Gene Signature in Pediatric Inflammatory Bowel Disease: A Matched-case Control Pilot Study. Inflamm. Bowel Dis. 2018, 24, 1321-1334. [CrossRef]

72. Broer, S.; Broer, A. Amino acid homeostasis and signalling in mammalian cells and organisms. Biochem. J. 2017, 474, 1935-1963. [CrossRef]

73. Morgan, X.C.; Tickle, T.L.; Sokol, H.; Gevers, D.; Devaney, K.L.; Ward, D.V.; Reyes, J.A.; Shah, S.A.; LeLeiko, N.; Snapper, S.B.; et al Dysfunction of the intestinal microbiome in inflammatory bowel disease and treatment. Genome Biol. 2012, 13, R79. [CrossRef] [PubMed]

74. Erickson, A.R.; Cantarel, B.L.; Lamendella, R.; Darzi, Y.; Mongodin, E.F.; Pan, C.; Shah, M.; Halfvarson, J.; Tysk, C.; Henrissat, B.; et al. Integrated metagenomics/metaproteomics reveals human host-microbiota signatures of Crohn's disease. PLoS ONE 2012, 7, e49138. [CrossRef] [PubMed]

75. Ahmed, I.; Roy, B.C.; Khan, S.A.; Septer, S.; Umar, S. Microbiome, Metabolome and Inflammatory Bowel Disease. Microorganisms 2016, 4, 20. [CrossRef] [PubMed]

76. Lavelle, A.; Sokol, H. Gut microbiota-derived metabolites as key actors in inflammatory bowel disease. Nat. Rev. Gastroenterol. Hepatol. 2020, 17, 223-237. [CrossRef] [PubMed]

77. Nikolaus, S.; Schulte, B.; Al-Massad, N.; Thieme, F.; Schulte, D.M.; Bethge, J.; Rehman, A.; Tran, F.; Aden, K.; Hasler, R.; et al. Increased Tryptophan Metabolism Is Associated With Activity of Inflammatory Bowel Diseases. Gastroenterology 2017, 153, 1504-1516.e2. [CrossRef] [PubMed]

78. Williams, B.B.; Van Benschoten, A.H.; Cimermancic, P.; Donia, M.S.; Zimmermann, M.; Taketani, M.; Ishihara, A.; Kashyap, P.C.; Fraser, J.S.; Fischbach, M.A. Discovery and characterization of gut microbiota decarboxylases that can produce the neurotransmitter tryptamine. Cell Host Microbe 2014, 16, 495-503. [CrossRef]

79. Zelante, T.; Iannitti, R.G.; Cunha, C.; De Luca, A.; Giovannini, G.; Pieraccini, G.; Zecchi, R.; D'Angelo, C.; Massi-Benedetti, C.; Fallarino, F; et al. Tryptophan catabolites from microbiota engage aryl hydrocarbon receptor and balance mucosal reactivity via interleukin-22. Immunity 2013, 39, 372-385. [CrossRef]

80. Venkatesh, M.; Mukherjee, S.; Wang, H.; Li, H.; Sun, K.; Benechet, A.P.; Qiu, Z.; Maher, L.; Redinbo, M.R.; Phillips, R.S.; et al. Symbiotic bacterial metabolites regulate gastrointestinal barrier function via the xenobiotic sensor PXR and Toll-like receptor 4 . Immunity 2014, 41, 296-310. [CrossRef]

81. Hasnain, S.Z.; Tauro, S.; Das, I.; Tong, H.; Chen, A.C.; Jeffery, P.L.; McDonald, V.; Florin, T.H.; McGuckin, M.A. IL-10 promotes production of intestinal mucus by suppressing protein misfolding and endoplasmic reticulum stress in goblet cells. Gastroenterology 2013, 144, 357-368. e9. [CrossRef] [PubMed]

82. Gao, J.; Xu, K.; Liu, H.; Liu, G.; Bai, M.; Peng, C.; Li, T.; Yin, Y. Impact of the Gut Microbiota on Intestinal Immunity Mediated by Tryptophan Metabolism. Front. Cell Infect. Microbiol. 2018, 8, 13. [CrossRef] [PubMed]

83. Yano, J.M.; Yu, K.; Donaldson, G.P.; Shastri, G.G.; Ann, P.; Ma, L.; Nagler, C.R.; Ismagilov, R.F.; Mazmanian, S.K.; Hsiao, E.Y. Indigenous bacteria from the gut microbiota regulate host serotonin biosynthesis. Cell 2015, 161, 264-276. [CrossRef] [PubMed]

84. He, F.; Wu, C.; Li, P.; Li, N.; Zhang, D.; Zhu, Q.; Ren, W.; Peng, Y. Functions and Signaling Pathways of Amino Acids in Intestinal Inflammation. Biomed. Res. Int. 2018, 2018, 9171905. [CrossRef]

85. Paul, B.D.; Snyder, S.H. The unusual amino acid L-ergothioneine is a physiologic cytoprotectant. Cell Death Differ. 2010, 17, 1134-1140. [CrossRef]

86. Shimizu, T.; Masuo, Y.; Takahashi, S.; Nakamichi, N.; Kato, Y. Organic cation transporter Octn1-mediated uptake of food-derived antioxidant ergothioneine into infiltrating macrophages during intestinal inflammation in mice. Drug Metab. Pharm. 2015, 30, 231-239. [CrossRef]

87. Kato, Y.; Kubo, Y.; Iwata, D.; Kato, S.; Sudo, T.; Sugiura, T.; Kagaya, T.; Wakayama, T.; Hirayama, A.; Sugimoto, M.; et al. Gene knockout and metabolome analysis of carnitine/organic cation transporter OCTN1. Pharm. Res. 2010, 27, 832-840. [CrossRef]

88. Magro, F.; Vieira-Coelho, M.A.; Fraga, S.; Serrao, M.P.; Veloso, F.T.; Ribeiro, T.; Soares-da-Silva, P. Impaired synthesis or cellular storage of norepinephrine, dopamine, and 5-hydroxytryptamine in human inflammatory bowel disease. Dig. Dis. Sci. 2002, 47, 216-224. [CrossRef] [PubMed]

89. Burczynski, M.E.; Peterson, R.L.; Twine, N.C.; Zuberek, K.A.; Brodeur, B.J.; Casciotti, L.; Maganti, V.; Reddy, P.S.; Strahs, A.; Immermann, F; et al. Molecular classification of Crohn's disease and ulcerative colitis patients using transcriptional profiles in peripheral blood mononuclear cells. J. Mol. Diagn 2006, 8, 51-61. [CrossRef]

90. Hong, S.K.; Maltz, B.E.; Coburn, L.A.; Slaughter, J.C.; Chaturvedi, R.; Schwartz, D.A.; Wilson, K.T. Increased serum levels of L-arginine in ulcerative colitis and correlation with disease severity. Inflamm. Bowel Dis. 2010, 16, 105-111. [CrossRef]

91. McCole, D.F. The epithelial glycine transporter GLYT1: Protecting the gut from inflammation. J. Physiol. 2010, 588, 1033-1034. [CrossRef] [PubMed]

92. Smith, R.J. Glutamine metabolism and its physiologic importance. J. Parenter. Enter. Nutr. 1990, 14, 40S-44S. [CrossRef] 
93. Windmueller, H.G. Glutamine utilization by the small intestine. Adv. Enzymol. Relat. Areas Mol. Biol. 1982, 53, $201-237$.

94. Bergmann, K.C.; Waldman, R.H. Stimulation of secretory antibody following oral administration of antigen. Rev. Infect. Dis. 1988, 10, 939-950. [CrossRef] [PubMed]

95. Patterson, A.D.; Gonzalez, F.J.; Idle, J.R. Xenobiotic metabolism: A view through the metabolometer. Chem. Res. Toxicol. 2010, 23, 851-860. [CrossRef]

96. Rizzello, F.; Spisni, E.; Giovanardi, E.; Imbesi, V.; Salice, M.; Alvisi, P.; Valerii, M.C.; Gionchetti, P. Implications of the Westernized Diet in the Onset and Progression of IBD. Nutrients 2019, 11, 1033. [CrossRef]

97. Altajar, S.; Moss, A. Inflammatory Bowel Disease Environmental Risk Factors: Diet and Gut Microbiota. Curr. Gastroenterol. Rep. 2020, 22, 57. [CrossRef] [PubMed]

98. Dunn, K.A.; Moore-Connors, J.; MacIntyre, B.; Stadnyk, A.; Thomas, N.A.; Noble, A.; Mahdi, G.; Rashid, M.; Otley, A.R.; Bielawski, J.P.; et al. The Gut Microbiome of Pediatric Crohn's Disease Patients Differs from Healthy Controls in Genes That Can Influence the Balance Between a Healthy and Dysregulated Immune Response. Inflamm. Bowel Dis. 2016, 22, 2607-2618. [CrossRef]

99. Martini, D.; Del Bo, C.; Tassotti, M.; Riso, P.; Del Rio, D.; Brighenti, F.; Porrini, M. Coffee Consumption and Oxidative Stress: A Review of Human Intervention Studies. Molecules 2016, 21, 979. [CrossRef]

100. Baldissera, M.D.; Souza, C.F.; Doleski, P.H.; Zeppenfeld, C.C.; Descovi, S.; Da Silva, A.S.; Baldisserotto, B. Xanthine oxidase activity exerts pro-oxidative and pro-inflammatory effects in serum of silver catfish fed with a diet contaminated with aflatoxin B1. J. Fish. Dis. 2018, 41, 1153-1158. [CrossRef]

101. Neubauer, K.; Kempinski, R.; Matusiewicz, M.; Bednarz-Misa, I.; Krzystek-Korpacka, M. Nonenzymatic Serum Antioxidant Capacity in IBD and Its Association with the Severity of Bowel Inflammation and Corticosteroids Treatment. Medicina 2019, 55, 88. [CrossRef] [PubMed]

102. Chetcuti Zammit, S.; Ellul, P.; Girardin, G.; Valpiani, D.; Nielsen, K.R.; Olsen, J.; Goldis, A.; Lazar, D.; Shonova, O.; Novakova, M.; et al. Vitamin D deficiency in a European inflammatory bowel disease inception cohort: An Epi-IBD study. Eur. J. Gastroenterol. Hepatol. 2018, 30, 1297-1303. [CrossRef] [PubMed]

103. Hausmann, J.; Kubesch, A.; Amiri, M.; Filmann, N.; Blumenstein, I. Vitamin D Deficiency is Associated with Increased Disease Activity in Patients with Inflammatory Bowel Disease. J. Clin. Med. 2019, 8, 1319. [CrossRef]

104. Lopez-Munoz, P.; Beltran, B.; Saez-Gonzalez, E.; Alba, A.; Nos, P.; Iborra, M. Influence of Vitamin D Deficiency on Inflammatory Markers and Clinical Disease Activity in IBD Patients. Nutrients 2019, 11, 1059. [CrossRef] [PubMed]

105. Mechie, N.C.; Mavropoulou, E.; Ellenrieder, V.; Petzold, G.; Kunsch, S.; Neesse, A.; Amanzada, A. Serum vitamin D but not zinc levels are associated with different disease activity status in patients with inflammatory bowel disease. Medicine 2019, 98 , e15172. [CrossRef] [PubMed]

106. Limketkai, B.N.; Singla, M.B.; Rodriguez, B.; Veerappan, G.R.; Betteridge, J.D.; Ramos, M.A.; Hutfless, S.M.; Brant, S.R. Levels of Vitamin D Are Low After Crohn's Disease Is Established But Not Before. Clin. Gastroenterol. Hepatol. 2020, 18, 1769-1776. [CrossRef]

107. Bikle, D.D.; Malmstroem, S.; Schwartz, J. Current Controversies: Are Free Vitamin Metabolite Levels a More Accurate Assessment of Vitamin D Status than Total Levels? Endocrinol. Metab. Clin. 2017, 46, 901-918. [CrossRef]

108. Aksan, A.; Tugal, D.; Hein, N.; Boettger, K.; Caicedo-Zea, Y.; Diehl, I.; Schumann, C.; Armbruster, F.P.; Stein, J. Measuring Vitamin D Status in Chronic Inflammatory Disorders: How does Chronic Inflammation Affect the Reliability of Vitamin D Metabolites in Patients with IBD? J. Clin. Med. 2020, 9, 547. [CrossRef]

109. Bermejo, F.; Algaba, A.; Guerra, I.; Chaparro, M.; De-La-Poza, G.; Valer, P.; Piqueras, B.; Bermejo, A.; Garcia-Alonso, J.; Perez, M.J.; et al. Should we monitor vitamin B12 and folate levels in Crohn's disease patients? Scand. J. Gastroenterol. 2013, 48, 1272-1277. [CrossRef]

110. Martin, J.; Radeke, H.H.; Dignass, A.; Stein, J. Current evaluation and management of anemia in patients with inflammatory bowel disease. Expert Rev. Gastroenterol. Hepatol. 2017, 11, 19-32. [CrossRef] [PubMed]

111. Gioxari, A.; Amerikanou, C.; Papada, E.; Zioga, E.; Georgoulis, A.D.; Bamias, G.; Kaliora, A.C. Serum Vitamins D, B9 and B12 in Greek Patients with Inflammatory Bowel Diseases. Nutrients 2020, 12, 3734. [CrossRef] [PubMed]

112. Keshteli, A.H.; Tso, R.; Dieleman, L.A.; Park, H.; Kroeker, K.I.; Jovel, J.; Gillevet, P.M.; Sikaroodi, M.; Mandal, R.; Fedorak, R.N.; et al. A Distinctive Urinary Metabolomic Fingerprint Is Linked With Endoscopic Postoperative Disease Recurrence in Crohn's Disease Patients. Inflamm. Bowel Dis. 2018, 24, 861-870. [CrossRef] [PubMed]

113. Sugihara, K.; Morhardt, T.L.; Kamada, N. The Role of Dietary Nutrients in Inflammatory Bowel Disease. Front. Immunol. 2018, 9, 3183. [CrossRef]

114. Ding, N.S.; McDonald, J.A.K.; Perdones-Montero, A.; Rees, D.N.; Adegbola, S.O.; Misra, R.; Hendy, P.; Penez, L.; Marchesi, J.R.; Holmes, E.; et al. Metabonomics and the Gut Microbiome Associated With Primary Response to Anti-TNF Therapy in Crohn's Disease. J. Crohns Colitis 2020, 14, 1090-1102. [CrossRef] [PubMed] 